\title{
KONSEP HIKMAT AL-TASYRÎ' SEBAGAI ASAS EKONOMI DAN \\ KEUANGAN BISNIS ISLAM MENURUT ALI AHMAD AL-JURJAWI (1866-1961M) DALAM KITAB HIKMAT AL-TASYRÎ' WA FALSAFATUHU
}

\author{
${ }^{1}$ SUDIRMAN M. JOHAN, ${ }^{2}$ NURHADI, ${ }^{3}$ AKHMAD MUJAHIDIN \\ ${ }^{4}$ AHMAD ROFIQ, ${ }^{5}$ MAWARDI MUHAMMAD SALEH \\ 1,3,5UIN Sultan Syarif Kasim Riau, ${ }^{2}$ STAI AI-Azhar Pekanbaru \\ ${ }^{4}$ UIN Wali Songo Semarang. \\ alhadicentre@yahoo.co.id
}

\begin{abstract}
Ali Ahmad Al-Jurjawi (1866-1961) a modernist from the Egyptian city of Jarja. Al-Jurjawi lived in a time of shock, known as the Egyptian revolution from the clutches of France. European colonization of the Islamic world (Egypt), which tends to manage the economy with a conventional (secular) system. These conditions affect the construction of scholarship which is occupied by Al-Jurjawi, plus the difficulty of finding the ideal books, especially regarding Islamic law and wisdom or secrets that exist in Islamic teachings. Starting from such a situation Al-Jurjawi much got the idea of philosophy and thought and determined to write a book that discusses the wisdom of Islamic Shari'ah, which is named Hikmat al-Tasyrî 'wa Falsafatuhu. Then how kosep wisdom al-Tashrî 'became the economic and financial principles of Islamic business according to Al-Jurjawi in the book. The result, the concept of wisdom al-Tasyrî 'Al-Jurjawi is amazing wisdom, astonishing mind and satisfy the heart of the shari'ah of the divine religion aims to know God, inhumanizing, knowing how to worship and Think about it by establishing the law necessary to be done amar ma'ruf nahi mungkar and benefit servants of the world and the hereafter. The reason for wisdom of al-Tashrî 'as the economic and financial principle in Islamic business according to Al-Jurjawi, to realize submission to the Shari'ah of Allah; preserving the Sunnah of the Prophet; keep away from the forbidden; foster moral development; realizing brotherhood and unity. All according to Al-Jurjawi contains benefit the world and the hereafter, in an effort to know God by worshiping and ma'ruf nahi munkar and morally noble character. It is embodied in the concept of hablum minnallâh wa
\end{abstract}


Sudirman M. Johan, Nurhdi, Akhmad Mujahidin, Ahmad Rofiq, Mawardi

Muhammad Saleh; Konsep Hikmat Al-Tasyrî' sebagai Asas Ekonomi dan

Keuangan Bisnis Islam Menurut Ali Ahmad Al-Jurjawi (1866-1961M) dalam Kitab Hikmat Al-Tasyrî' Wa Falsafatuhu

minannâs. Benefit as the principle of innovation of economic and financial activities in contemporary Islamic business according to the researchers lies in the wisdom of ihyâu al-Mawât his Al-Jurjawi is to innovate in business for benefit people.

Keyword : Concept, Wisdom of Al-Tashrî', Islamic Financial Economics Business Principles, Ali Ahmad Al-Jurjawi, Hikmat Al-Tasyrî’ Wa Falsafatuhu

\section{PENDAHULUAN}

Sistem Ekonomi Syarî‘ah diawali pada masa Muhammad saw. Pada masa itu, semua persoalan ekonomi merujuk pada ketentuan syariat (nash qur'an dan hadis) (Nurhadi: 2018; Idris Ismail, 2017: 1; Didiek, 2013: 1; Daud, 2012: 23). Setelah Nabi wafat, lalu digantikan oleh Abu Bakar, Umar, Usman dan Ali, berlanjut ke dinasti-dinasti dalam kekhalifahan dalam Islam, yang ditutup dengan kekhalifahan Turki Usmani. Runtuhnya kekhalifahan Turki Usmani, tidak disadari menjadi awal keruntuhan ekonomi Islam (Daud, 2012: 23). Ekonomi Syarî‘ah baru muncul kembali pada tahun 1963, dengan berdirinya bank tanpa bunga di desa Mit Ghamr Mesir oleh Abdu al-Hamid An-Nagar (Ahmad Najjar) (Ahmad, 1972: 19; Syafi'l, 2011: 19; Abbas, 2013: 109-110; Muhammad, 2014: 19; Anif, 2014: 27). Ini menjadi awal mula dan dasar berdirinya lembaga keuangan syarî'ah moderen di dunia (Anif, 2014: 24).

Ekonomi dan bisnis syarî́ah perkembangannya sejalan dengan prinsip-prinsip syarî‘ah. Oleh karena itu, keterlibatan ulama dalam ekonomi syarî'ah menjadi urgen (penting), yaitu untuk berijtihad memberikan solusi bagi permasalahan ekonomi keuangan yang muncul baik pada skala mikro maupun makro, merancang akadakad syarî‘ah untuk kebutuhan produk-produk bisnis di berbagai lembaga keuangan syari'ah, mengawal dan menjamin seluruh produk perbankan dan keuangan syarî‘ah dijalankan sesuai syarî‘ah. Perkembangan tegnologi mengakibatkan berkemabangnya transaksi bisnis ekonomi yang sangat inovasi. Kehadiran inovasi tersebut dalam rangka memenuhi kebutuhan masyarakat yang cenderung moderen dan global. Sesuai khittahnya, syariat Islam mempunyai tujuan untuk kemashlahatan umat dunia akhirat. Oleh karena itu, maqâshid alsyarî'ah versi al-Syathibi dan alJurjawi sangat penting sebagai dasar rekontruksi inovasi produk akad dalam melengkapi ekonomi dan bisnis syarî‘ah dengan tujuan gerakan ekonomi Islam dapat dijalankan dalam masyarakat sesuai dengan maqâshid al-Syarî'ah yaitu kemashlahatan sesuai syariat. Maka menurut peneliti, prinsip utama dalam formulasi ekonomi Islam dan produk keuangan adalah Mashlahah (Nurhadi: 2018; Ali, 1994 M/ 1414 H: 
Al-Fikra: Jurnal IImiah Keislaman, Vol. 17, No. 1, Januari - Juni, 2018 (147 189)

5; Faisal, 2006: 7; Sabariyah, 2011: 12).

Ali Ahmad Al-Jurjawi (18661961) seorang modernis dari kota Jarja' Mesir. Al-Jurjawi menuangkan ide filsafat serta pemikiran dalam kitabnya yang banyak membahas tentang hikmah-hikmah atau rahasia-rahasia syariat Islam, yang diberi nama Hikmat al-Tasyrî́ wa Falsafatuhu. Al-Jurjawi di dalam kitabnya, tidak menggunakan istilah maqâshid al-Syarî'ah melainkan mengunakan istilah Hikmat al-Tasyrî' (Sabariyah, 2011: 2). Menurut ulama Ushûl Fiqih, Hikmat al-Tasyrî̀ di identifikasikan sebagai maqâshid alSyarî'ah sebagaimana pendapat Ibnu Rusdiy (Muhammad, $1301 \mathrm{H}$ : 8), Ibnu Qayyîm al-Jauziyyah (Ibnu Qayyim, 1996: 37), Ibnu Asyûr (Ibnu Asyur, 2001: 3; Irfandi, 2014: 7; Andriyaldi, 2014: 25), Yûsûf alQardlâwi (Yusuf, 2006: 17), Wahbah al-Zuhaili (Wahbah, 1986: 1017; Ghofar, 2009: 119) dan Jaser Auda (Jasser, 2008: 5; Galuh, 2014: 56). Menurut peneliti Maqâshid alSyarî'ah sangat penting sehingga ulama menjadikannya pokok ilmu yang berdiri sendiri (Muhammad Ibnu, 2001: 190-194). Studi tentang maqâshid al-Syarî'ah banyak dilakukan para ulama dengan berbagai pendekatan (Ibnû Qayyîm, 1996: 37). Di antara ulama yang membahas hikmat al-Tasyrî' adalah Ali Ahmad al-Jurjawi (Al-Muzakkir, 2017: 6).

Menurut al-Jurjawi, pengungkapan hikmah-hikmat tersebut menjadi sebuah keniscayaan, agar umat Islam kembali kepada khittah (al-Qur'an dan hadis), sehingga menghidupkan kembali muamalah ekonomi Islam, yang menurut al-Jurjawi selama beberapa dekade pada masa kehidupan beliau, perekonomian ummat didominasi dan terkontaminasi oleh sistem konvensional (bunga riba), misalnya sistem ekonomi kapitalis, sosialis dan sekuleris. Keinginannya untuk mengembalikan kembali sistem ekonomi Islam yang sudah runtuh diakibatkan sekulerisme didunia Islam, beliau tuangkan dalam kitabnya hikmat al-Tasyri' wafalsafatuhu pada juz dua sub pembahasan muamalah dan transasksi ekonomi dan keuangan (muamalah iqtishadiyah).

Menurut peneliti kitab alJurjawi yang sangat menarik untuk dipelajari dan diteliti, uniknya beliau dalam menulis kitab tersebut tidak menjelaskan secara detail menggunakan metode seperti apa dalam menetapkan Hikmat al-Tasyrî' (Maqâshid Syarî'ah), Dalam penelitian ini setiap kalimat atau kata-kata Hikmat al-Tasyrî' atau Hikmah Syariah dipersamakan dengan kata atau kalimat Maqâshid Syariah, Illat, Makna, Ma'akhizd, Mahâsin, Asrâr, Hakikat, Manfaat, Mashlahah dan Filsafat Hukum Islam. Sehingga pada satu pembahasan ditemukan al-Jurjawi menggunakan Nash al-Qur'an dan al-Hadits, dilain kajian menggunakan dalil al-Qur'an saja. Pada bab lain terkadang hanya menggunakan Hadis saja, bahkan terkadang tidak menggunakan dalil apapun kecuali ijtihad pemikiran saja (Filasafat Hukum Islam/Logika Filsafat). Model 
Sudirman M. Johan, Nurhdi, Akhmad Mujahidin, Ahmad Rofiq, Mawardi

Muhammad Saleh; Konsep Hikmat Al-Tasyrî' sebagai Asas Ekonomi dan

Keuangan Bisnis Islam Menurut Ali Ahmad Al-Jurjawi (1866-1961M) dalam Kitab Hikmat Al-Tasyrî’ Wa Falsafatuhu

inilah yang menjadi penasaran peneliti yang berkeinginan menggali metode al-Jurjawi dalam menetapkan hikmah syariah atau hikmat al-Tasyri' lewat karyanya itu, apalagi jika di tinjua dalam bab Muâmalah lqtishâdiyah tentu tambah menarik untuk diteliti.

Berdasarkan latar belakang inilah, maka penulis akan meneliti kitab al-Jurjawi dalam menetapkan hikmat al-tasyrî' sebagai asas ekonomi dan keuangan atau maqâshid bisnis dalam hikmah muamalah. Ruang lingkup hikmah syarî'ah ekonomi dan bisnis akan difokuskan pada bisnis keuangan syarî‘ah. Permasalahan utama yang menjadi fokus dalam penelitian ini, bagaimana konsep hikmat al-Tasyrî' menurut Ali Ahmad al-Jurjawi dan mengapa Ali Ahmad al-Jurjawi menawarkan konsep hikmat alTasyrî' sebagai asas ekonomi dan keuangan dalam bisnis Islam seperti dalam kitab Hikmat al-Tasyri' wa Falsafatuhu.

\section{LANDASAN TEORI}

1. Konsep Maqâsid alSyarî’ah

\subsection{Subtansi dan \\ Perkembangan \\ Maqâsid al-Syarî'ah}

Maqâsid al-Syarî'ah ditinjau

dari lughâwiy (bahasa), terdiri dari dua kata, yakni maqâsid dan alSyarî'ah. Maqâsid adalah bentuk jama' dari maqâsid yang berarti kesengajaan atau tujuan (Nurhadi: 2018; Hans Wehr, 1980: 767). Kata maqshud-maqâsid dalam IImu Nahwu disebut dengan maf'ûl bih yaitu sesuatu yang menjadi obyek.
Jadi, kata tersebut dapat diartikan sebagai "tujuan" atau "beberapa tujuan". Sedangkan al-Syarî'ah, merupakan bentuk subyek dari akar kata syara'a yang artinya adalah jalan menuju sumber air sebagai sumber kehidupan (Ibn Manzur, t.th: 175). Syarî'ah secara bahasa juga berarti:

yang berarti jalan menuju sumber air. Jalan menuju sumber air ini dapat juga dikatakan sebagai jalan kearah sumber pokok kehidupan (Asafri, 1996: 61). Menurut Al Izz bin Abdul Salam, maqâshid syariah adalah syariat itu semuanya mengandung nilai maslahah yang bertujuan menolak kejahatan atau menarik kebaikan (Al-Izzuddin, t.th: 9). Menurut Al Khadimi, maqashid syariah adalah sebagai prinsip Islam yang lima yaitu menjaga agama, jiwa, akal, keturunan dan harta (Nuruddin, 1998: 50). Menurut Satria Effendi M. Zein, maqasid al-syari'ah adalah tujuan Allah dan Rasul-Nya dalam merumuskan hukum-hukum Islam.

Tujuan itu dapat ditelusuri dalam ayat-ayat al-Qur'an dan hadis sebagai alasan logis bagi rumusan suatu hukum yang berorientasi kepada kemaslahatan manusia (Satria, 2005: 233; La Jamaa, 2011: 1255). Kaitan dengan maqâshid syarî'ah tersebut, Imam al-Syathibiy mempergunakan kata yang berbedabeda yaitu maqâshid syarî'ah, almaqâshid al-Syar'iyyah fi alSyarî'ah, dan maqâshid min syar'i al-Hukm. Meskipun dengan katakata yang berbeda, Asafri Jaya Bakri berpendapat bahwa kata tersebut 
Al-Fikra: Jurnal IImiah Keislaman, Vol. 17, No. 1, Januari - Juni, 2018 (147 189)

mengandung tujuan yang sama, yaitu tujuan hukum yang diturunkan oleh Allâh swt. Ungkapan alSyâthibîy: "Sesungguhnya syari'at itu bertujuan mewujudkan kemashlahahan manusia di dunia dan di akhiral" dan "Hukum-hukum disyari'atkan untuk kemashlahahan hamba", Kemaslahatan yang akan diwujudkan itu menurut al-Syâtibîy terbagi kepada tiga tingkatan, yaitu kebutuhan dharuriyat, kebutuhan hajiyat, dan kebutuhan tahsiniyat (Abû Ishâq, 1997: 324; Asafri, 1996: 63-64). Memberikan pengertian bahwa kandungan Maqâshid alSyarî'ah adalah kemashlahahan umat manusia. Menurut istilah, ulama Ushul Fiqih adalah makna dan tujuan yang dikehendaki syara' dalam mensyariatkan suatu hukum bagi kemashlahahan umat manusia, disebut juga dengan asrâr asysyari'ah yaitu rahasia-rahasia yang terdapat di balik hukum yang ditetapkan oleh syara', berupa kemashlahahan bagi umat manusia, baik di dunia maupun di akhirat (Abdul Aziz, 1996: 1108). Oleh karena itu, Asafri Jaya Bakri memandang bahwa kandungan maqâshid syarî'ah adalah kemashlahahan. Kemashlahahan itu, melalui maqâshid syarî'ah tidak hanya dilihat dalam arti teknis belaka, tetapi dalam upaya dinamika dan pengembangan hukum dilihat sebagai susuatu yang mengandung nilai filosofis dari hukum-hukum yang di syari'atkan Allâh swt terhadap manusia (Nurhadi: 2018; Asafri, 1996: 65-66).

\subsection{Mashlahah dan Penerapan Maqâshid dalam Bisnis Syarî‘ah}

Berdasarkan asumsi bahwa rumusan ekonomi dan bisnis syari'ah adalah mashlahah. Dalam buku hasil penelitian yang ditulis oleh Asafri Jaya Bakri, beliau mengemukakan al-mashâlih almursâlah dan az-zâri'ah sebagai metode ijtihad dengan corak penalaran istihlah yang harus dikembangkan dengan menunjukkan urgensi pertimbangan Maqâshid alSyarî'ah di dalam metode tersebut (Asafri, 1996: 142). Oleh karena itu, menurut penulis perlu kiranya membahas mashlahah (Asafri, 1996: 142) lebih lanjut kaitannya dengan ekonomi dan bisnis syari'ah (Yusdani, 2017 Jam 20.05 Wib).

Dalam pemikiran ushul fiqih terdapat tiga cara menentukan legalitas mashlahah (Asafri, 1996: 144-146), yaitu:

1) Mashlahah yang legalitasnya berdasarkan tunjukan dari suatu nash, baik al-Qur'an maupun hadits (mashlahah mu'tabârah). Misalnya, dalam ayat al-Qur'an yang QS. Surat al-Baqarah, ayat 275.

2) Mashlahah yang ditolak legalitasnya oleh al-Syarî' (mashlahah mulghah). Artinya sesuatu yang dilihat manusia sebagai suatu kemashlahahan, akan tetapi bertentangan dengan alsyari' seperti yang ditunjukkan oleh nash di atas. Maka alasan penerapan kemashlahahan demikian tidak bisa 
Sudirman M. Johan, Nurhdi, Akhmad Mujahidin, Ahmad Rofiq, Mawardi

Muhammad Saleh; Konsep Hikmat Al-Tasyrî' sebagai Asas Ekonomi dan

Keuangan Bisnis Islam Menurut Ali Ahmad Al-Jurjawi (1866-1961M) dalam Kitab Hikmat Al-Tasyrî’ Wa Falsafatuhu

dibenarkan. Misalnya, pengembangan harta atau usaha secara ribawi dalam ayat al-Qur'an QS. Surat alNisa', ayat 161.

3) Mashlahah yang tidak terdapat legalitas nash baik terhadap keberlakuan maupun ketidakberlakuannya (mashlahah al-mursâlah). Artinya mashlahah yang tidak diperintahkan di dalam alQur'an dan hadîts, akan tetapi tidak bertentangan terhadap keduanya. Mislanya, pendirian bank syari'ah (Heri, 2008: 43) sebagai lembaga yang menghubungkan antara pemilik modal dan pekerja. Dalam al-Qur'an dan hadîts tidak ada perintah untuk mendirikan Lembaga Perbankan Syari'ah, akan tetapi keberadaannya tidak di larang oleh al-Qur'an dan hadits. Keberadaan Lembaga Perbankan mendatangkan manfaat bagi masyarakat dan manfaat tersebut tidak bertentangan dengan nash seperti prinsip bagi hasil (akad mudhârabah) (Yazid, 2009: 101) di antara kedua belah pihak akan mendapatkan manfaat dari hasil kerja sama tersebut (Nurhadi: 2018; Yusdani, 2017 Jam 20.05 Wib).

Dari tiga mashlahah di atas, dapat dikatakan bahwa tidak semua mashlahah itu dibenarkan oleh syara', tetapi ada juga mashlahah yang bertentangan dengan syara'. Mashlahah yang sangat urgen untuk dijadikan pengembangan kajian Hukum Islam juga berhubungan dengan masalah-masalah ekonomi dan bisnis syari'ah (Asafri, 1996: 149). Mashlahah al-Mursalah ini dapat dijadikan sebagai sumber hukum dengan mengacu kepada pengembangan Maqâshid alSyarî'ah telah dijelaskan sebelumnya, yaitu Maqâshid alDlarûriyât, Maqâshid al-hajiyat, dan Maqâshid al-Tahsinîyât, sehingga kemashlahahan benar-benar terwujud dalam kehidupan umat manusia (Yusdani, 2017 Jam 20.05 Wib).

\section{Penelitian yang Relevan}

Sejauh penelusuran penulis, penelitian yang membahas mengenai hikmah syarî́ah dalam ekonomi dan keuangan Islam menurut Ali Ahmad al-Jurjawi belum ada. Terdapat sebuah buku yang penulis temukan yang sangat erat kaitannya dengan penelitian ini, yaitu Maqâshid Bisnis dan Keuangan Islam (sintesis fiqih dan ekonomi) (Oni dan Adiwarman, 2016). Sedangkan penelitian studi naskah kitab Hikmat al-Tasyrî' wa Falsafatuhu karangan Imam Ali Ahmad al-Jurjawi dalam bentuk disertasi belum peneliti temukan. Meskipun demikian, peneliti menemukan sebuah Tesis yang ditulis oleh Sabariah Mahasiswi Pascasarjana Universitas Islam Negeri Sultan Syarif Kasim Riau lulusan tahun 2011 dengan Judul: "Kerangka Berpikir Ali Ahmad alJurjawi Menetapkan hikmat al-Tasyrî' 
Al-Fikra: Jurnal IImiah Keislaman, Vol. 17, No. 1, Januari - Juni, 2018 (147 189)

pada Kitab Hikmat al-Tasyrî' Wa Falsafatuh. Dalam tesis tersebut penulis mengupas logika berpikir istinbath hikmat al-Tasyrî'Syarî'ah Islam dari kajian epistimologi, sedangkan disertasi ini membahas hikmat al-Tasyrî' dalam lingkup hikmat al-Tasyri' sebagai asas ekonomi dan keuangan Islam/Syarî‘ah dan relevansinya dengan tipologi keuangan kontemporer. Tesis Sabariah diatas sangat memberi inspirasi, kontribusi dan pemikiran serta teori yang dapat menjadi rujukan awal peneliti untuk membangun kerangka berpikir pendukung. Tesis Muzakkir berjudul "Hikmat Muâmalah Perspektif Ali Ahmad al-Jurjawi Dalam Kitab Hikmat al-Tasyrî' Wa Falsafatuhu, lulusan tahun 2017, membahas tentang muâmalah al-Ahwâl alSyakhshiyah, sedangkan muâmalah Iqtishâdiyah belum dibahas. Inilah perbedaan penelitian penulis. Aghnam Shofi dalam penelitiannya yang berjudul: "Puasa Menurut Syekh Ali Ahmad al-Jurjawi dalam kitab Hikmat al-Tasyrî' wa Falsafatuhu", fakultas usuluddin IAIN Walisongo Seamarang tahun 2004. Penelitian ini hanya membahas hikmah puasa saja, tentu hal ini sangat berbeda dengan penelitian ini yang lebih dikaitkan dengan ekonomi dan transaksinya. Berikut ini, penulis membahas beberapa penelitian dan artikel jurnal yang dapat dijadikan teori pembanding atau pendukung, di antaranya adalah:

a. Achmad Musyahid, Hikmat AtTasyri Dalam Daruriyyah AlHamzah, berisikan tentang
Rahasia hukum Islam sering juga disebut dengan asrâr al-Ahkâm atau hikmah at-tasyri. Rahasia hukum Islam terdapat dalam segala aspek ajaran Islam yang digambarkan dalam al-Daruriyat al-khamsah, yaitu menjaga agama, menjaga jiwa, menjaga akal, menjaga keturunan dan menjaga harta (Achmad, 2015). Sedangakan penelitian ini mengemukakan hikmat al-Tasyrî' perspektif Ali Ahmad al-Jurjawi di kaitkan dengan hikmah sebagai asas ekonomi dan keuangan dalam bisnis Islam.

b. Internasional Jurnal oleh Zulkifly bin Muda, Maqâshid al-Syarî'ah dan Kefatwaan: Pengharmonian Fatwa Demi Kepentingan Insan dan Alam, Jabatan Mufti Negeri Terengganu. Dalam artikel ini disimpulkan bahwa ijtihâd amat diperlukan pada masa kini akibat munculnya berbagai masalah dan persoalan-persoalan baru yang tidak ada dalam Nash, dan belum ada pada zaman Rasûlullâh. Islam membuka ruang untuk berijtihad dan umat Islam membutuhkan para ulama untuk membahas masalah tersebut (perkara kontemporer). Umat Islam bertanggungjawab mencari dan berijtihad tentang masalah-masalah baru, dengan merujuk pada kaedah Maqâshid al-Syarî'ah, sehingga para Mujtahîd Kontemporer dapat menyelesaikan persoalan muâmalah pada saat ini (Zulkifly, 2012).

c. Arif Wibowo, Islamic Finance-04 Maqâshid al-Syarî'ah: The 
Sudirman M. Johan, Nurhdi, Akhmad Mujahidin, Ahmad Rofiq, Mawardi

Muhammad Saleh; Konsep Hikmat Al-Tasyrî' sebagai Asas Ekonomi dan

Keuangan Bisnis Islam Menurut Ali Ahmad Al-Jurjawi (1866-1961M) dalam Kitab Hikmat Al-Tasyrî’ Wa Falsafatuhu

Ultimate Objective of Syaria. Dalam artikel ini disebutkan pentingnya peran Maqâshid dalam mengembangkan dan memberikan kepastian hukum syarî‘ah tentang keuangan Islam (Arif, t.th: website online).

d. M. Atho Mudzhar, Revitalisasi Maqâshid al-Syarî'ah dalam Pengembangan Ekonomi Syarî‘ah di Indonesia (Studi Kasus atas Fatwa-fatwa DSNMUI Tahun 2000-2006), Dosen Fakultas Syarî'ah dan Hukum UIN Jakarta. Tulisan ini menguji konsep Maqâshid al-Syarî'ah yang direvitalisasi sebagai hujjah dalam 53 fatwa Dewan Syarî‘ah Nasional (DSN) Majelis Ulama Indonesia (MUI) yang dikeluarkan selama periode 2000-2006. Inti dari Maqâshid alSyarî'ah adalah Mashlahah, oleh karena itu metode pengujiannya dilakukan dengan mencermati penggunaan kaidah-kaidah fikih yang terkait dengan mashlahah dalam fatwa-fatwa DSN-MUI. Studi ini menemukan bahwa dalam 50 dari 53 fatwa DSN-MUI dicantumkan kaidah fikih sebagai dasar pertimbangannya, sebelumnya telah dilengkapi dengan argumen Nash al-Quran dan Hadis, serta ljma' dan Qiyas. Terdapat 11 jenis kaidah fikih yang digunakan, minimal tercantum satu kaidah dan maksimal lima kaidah dalam sebuah fatwa. Frekuwensi penggunaan kaidah fikih secara keseluruhan sebanyak 134 kali, sehingga setiap fatwa rata-rata menggunakan $2 \mathrm{~s} / \mathrm{d} 5$ kaidah fikih. Kaidah fikih yang dominan digunakan ialah kaidah yang menyatakan bahwa asal hukum urusan muamalat dibolehkan selama tidak ada dalil yang mengharamkannya. Kaidah yang sangat umum ini, seringkali digunakan tanpa disertai dengan kaidah lain yang lebih khusus, sehingga mengesankan fatwa DSN-MUI cenderung permisif atau liberal, dan kurang dari sudut argumennya (Wijhat alNazâr), meskipun mungkin masih abash (M. Atho, 2006).

e. Sudin Haron, Mekanisme Kepatuhan Syarî́ah di Berbagai Negara dalam Karya Islamic Banking Rules and Regulations, terbitan Pelanduk Publication Selangor 1997. Artikel ini menjelaskan konsep mekanisme pelaksanaan syarî́ah di berbagai negara Timur Tengah dan ringkasan perbandingan fatwa di berbagai Dewan Pengawas Syarî‘ah sejumlah Bank Islam di Timur Tengah (Sudin, 1997).

\section{HASIL DAN PEMBAHASAN}

1. Pemikiran Ali Ahma AlJurjawi Tentang Hikmat AlTasyrî'

1.1. Ta'rif (Pengertian)
Hikmat Al-Tasyrî'
Syariat Islam datang untuk kemashlahatan hamba. Dalam syariat ada hikmah, rahasia hukum Islam sering juga disebut dengan asrâr al-ahkâm (Nurhadi: 2018; Supriyadi, 2010: 15; Depag RI, ,1997: 550) atau asrâr al-Tasyri atau hikmat al-Tasyri. Asrâr jika ditinjau 
Al-Fikra: Jurnal IImiah Keislaman, Vol. 17, No. 1, Januari - Juni, 2018 (147189)

dari sebab-sebab hukum disyariatkan dinamakan asrâr alTasyri atau rahasia pembinaan hukum dan jika ditinjau dari segi materi hukum dinamakan asrâr alahkâm atau rahasia hukum Islam (Achmad Musyahid, 2015: 223). Asrâr al-Ahkâm disebut juga dengan rahasia hukum Islam, ada juga yang menamankan dengan hikmat alTasyri' (Asrâr al-Tasyri) atau hikmat al-Syar'i (Asrâr al-Syari'ah). Hikmah rahasia hukum Islam bagian tidak terpisahkan dari filsafat hukum Islam itu sendiri dan asrar al-ahkam merupakan cabang dari falsafah hukum Islam (Nurhadi: 2018; M. Hasbi, 976: 38-39).

Hikmah adalah pengetahuan mengenai hakikat sesuatu dan pengetahuan mengenai sesuatu dalam hakikat itu, baik faedah maupun manfaat yang terkandung didalamnya. Pengetahuan tersebut mendorong pengetahuan manusia tentang hakikat untuk melakukan suatu perbuatan. Hikmah yang mendorong untuk melakukan suatu perbuatan atau sebagai Filsafat Praktis (Juhaya, 1989: 3).

Al-Qur'an sendiri menggunakan kata hikmah ini sebanyak 20 kali dengan tiga pengertian yaitu (Juhaya, 2008: 35): Pertama: Hikmah dalam pengertian al-Istibshâr fi al-umûr yaitu penelitian terhadap segala sesuatu secara cermat dan mendalam dengan menggunakan akal dan penalaran. Hikmah dengan pengertian ini terdapat dalam surat al-Imran ayat 164. Kedua: Hikmah berarti memahami rahasia-rahasia hukum dan maksud-maksudnya. Seperti yang terkandung dalam surah alBaqarah ayat 269. Ketiga: Hikmah dengan pengertian kenabian atau Nubuwwah. Hal ini terdapat dalam surat an-Nisa' ayat 54. Dari beberapa pengertian hikmah di atas, penulis menyimpulkan bahwa kata hikmah merealisasikan kemaslahatan dan menolak kerusakan dan merupakan tujuan akhir dari pensyari'atan hukum. Sejalan dengan pemahaman hikmah dalam ayat al-Quran yaitu menggali rahasia yang terdapat dalam syariat Islam (Sabariyah: 78; Abdul Karim, 2001: 201; Abdul Wahab, 2004: 6470; Ar-Raisuni, 2017 jam 13.10 Wib; Forum Kalimsada: 7-12).

Perbedaan filsafat dengan

hikmah, filsafat adalah langkah untuk mengetahui hakikat segala sesuatu sesuai dengan kemampuan manusia. Maka puncaknya adalah berkata dan berbuat sesuai dengan apa yang diketahui (al-falsafah awwaluha mahabbatu al-'ulum, wa awsathuha ma'rifatu haqa'iqi almawjudat bi-hasabi at-thaqati Iinsaniyyah wa akhiruha al-qawl wa al-'amal bi-ma yuwafiqu al-'ilma)' (Syamsuddin, 2018.Jam22.00.Wib). Berbeda dengan hikmah, filsafat tidak terkandung keharusan adanya pengetahuan tentang ketuhanan, tentang manfaat dan faedah sesuatu yang direnungkan atas dasar wahyu dari Allah. Sedangkan hikmah mengharuskan hal itu semua (Supriyadi: 17; Juhaya: 4 dan 6). Filsafat hukum Islam sendiri dapat dibagi menjadi tiga macam, yaitu:

1. Falsafah asy-syari'ah, yang mengungkapkan masalah ibadah, muammalah, jinayah 
Sudirman M. Johan, Nurhdi, Akhmad Mujahidin, Ahmad Rofiq, Mawardi

Muhammad Saleh; Konsep Hikmat Al-Tasyrî' sebagai Asas Ekonomi dan

Keuangan Bisnis Islam Menurut Ali Ahmad Al-Jurjawi (1866-1961M) dalam Kitab Hikmat Al-Tasyrî’ Wa Falsafatuhu

dan 'uqabah dari materi
hukum Islam. Falsafah
syari'ah mencakup asrar al-
ahkam, khasha'ilah al-
ahkam, mahasin al-ahkam
dan thawabi' al-ahkam.

2. Falsafah Tasyri', yaitu filsafat yang memancarkan hukum islam, menguatkan dan memeliharanya. Falsafah tasyri' meliputi ushul alahkam, maqasid al-ahkam dan qawa'id al-ahkam.

3. Hikmah at-Tasyri wa Falsafatuh, yaitu kajian mendalam dan radikal tentang prilaku mukallaf dalam mengamalkan hukum Islam sebagai undangundang dan jalan kehidupan yang lurus (Nurhadi: 2018; Tajul , 2008: 55-56).

Kata kedua dari hikmat alTasyri adalah al-Tasyri' atau syariah (H. Mohammad, 2010: 53). Kata Syara'a (syariah) bentuk mashdar dari syara'a (tanpa tasydid), sedangkan tasyri' bentuk mashdar dari syarra'a (bertasydid) (Syah Wali, 2005: 27). Pengetahuan tentang syarî'ah adalah pengetahuan tentang cara, proses, dasar dan tujuan Allah swt menetapkan hukum bagi tindak tanduk manusia dalam kehidupan keagamaan dan kehidupan keduniaan. Sedangkan pengetahuan tentang syari'at berarti Pengetahuan tentang hakikat dan rahasia dari hukum-hukum syara' yang telah ditetapkan oleh Allah swt (Nurhadi: 2018; Ismail Muhammad, 1991: 13).

Secara umum syarî'ah dapat dibedakan menjadi dua yaitu as-
Syarî'ah al-Islâmi min jihât al-Nash (syarî'ah dilihat dari sumbernya) dan as-Syarî'ah min jihât al-Tasassu' wa al-Syumûliyyah (tasyri' dilihat dari keluasaan pembahasan dan kandungannya). Tipe pertama terbatas pada syarî'ah yang dibentuk pada zaman Nabi Muhammad saw yaitu al-Qur'an dan as-Sunnah. Sedangkan tasyri' tipe kedua mencakup ljtihad Sahabat, Tabi'in dan ulama sesudahnya (Umar Sulaiman, 1991: 21). Maka syarî̀ah tidak terbatas pada pembentukan alQur'an dan as-Sunnah saja, akan tetapi syarî̀ah juga meliputi pemikiran, gagasan, dan ljtihâd ulama pada waktu tertentu atau kurun tertentu (Muhammad Kamil, 1989: 65), perbuatan manusia dan hasil pemikirannya disebut dengan istilah tasyri' wad'iy (Saebani: 49; Juhaya, 1997; 7; Sabariyah: 80).

Kata Hikmat al-Tasyrî' adalah gabungan dari kata hikmah dan kata Tasyri'. Setelah dibahas pengertian masing-masing kata, kata Hikmat alTasyrî' dapat dipahami sebagai jawaban dari pertanyaan apa yang memotivasi suatu hukum disyari'atkan kepada manusia (Ibrahim Basyuni, 1942: 237; Ismail Muhammad, 1991: 13). Secara umum al-Tasyri' meliputi ketiga aspek syariat yaitu Ibadah, Muamalah dan Akhlak (Ibrahim Basyuni, 1942: 237). Maka Hikmat al-Tasyrî' berarti menjawab semua pertanyaan tentang memotivasi halhal yang berhubungan dengan Ibadah, Muamalah dan Akhlak yang diperintahkan kepada manusia. Sebenarnya kata hikmah menunjukan pengertian tersebut. 
Al-Fikra: Jurnal IImiah Keislaman, Vol. 17, No. 1, Januari - Juni, 2018 (147 189)

Namun, menggabungkan kata tasyrî akan lebih menekankan pensyari'atan hukum Taklifi kepada manusia (Sabariyah: 83; Sa'di Abu: 97). Hikmat al-Tasyri' secara sederhana dapat diartikan sebagai hikmah diciptakan, dibuat, dan ditetapkannya hukum Islam (Nurhadi: 2018; Achmad Musyahid: 225).

Metode Penggalian Hikmat Al-Tasyrî' (Manhaj Asrar Al-Ahkam). Penggalian hikmat al-Syar'i atau Asrar al-Ahkam diperlukan metode yang dapat mengungkap segala rahasia-rahasia hukum, para ulama' mengadakan berbagai macam pendekatan untuk mengungkap rahasia-rahasia itu, adapun metode yang dikembangkan adalah sebagai berikut:

1) Metode Ta'ili atau Metode Qiyasi: Metode Ta'lili atau Metode Qiyasi, yaitu suatu metode penggalian hukumhukum islam melalui penganalisaan Illat (Motif) hukum (Ahmad Azhar, 1984: 135).

2) Metode Ta'wili: Metode Ta'wili adalah Metode penggalian rahasia-rahasia hukum islam melalui penyuguhan hukum islam dengan berpijak pada arti dibalik yang aslinya.

3) Metode Hikmi: Metode Hikmi adalah Metode pencarian rahasia hukum melalui pengungkapan hikmahhikmah yang terkandung di dalamnya. Misalnya, mengapa disyari'atkan shalat, karena sholat itu dapat mencegah segala gangguan kejiwaan, misalnya stress serta memberikan ketenangan yang tinggi, mensucikan diri dari perbuatab keji dan mungkar serta berdampak pada perbuatan yang positif (Nurhadi: 2018; Djamil: 263).

Wasail Asrar Al-Ahkam (Aspek Hikmat Al-Tasyrî). Sedangkan aspek-aspek yang mengungkapkan rahasia hukum Islam dapat diketahui melalui 2 (dua) sudut, yaitu sudut kebahasaan atau pun sudut ma'nanya, yaitu: 1). Sudut Bahasa, yaitu menerangkan hukum Islam dengan melihat teks ayat atau hadits yang teliti. 2). Sudut Ma'na, yaitu menerangkan rahasia hukum islam dengan melihat konteks makna pada ayat atau hadits yang diteliti.

Dhawabit Asrar Al-Ahkam (Wilayah Hikmat Al-Tasyrî). Menurut ibnu Rusdy, Asrar al-Ahkam hanya berlaku bagi hukum-hukum amaliah lahiriyah, belum sampai pada aqidah. Karena hukum aqidah diharuskan memakai dalii-dalil yang qoth'i yang tidak dipertentangkan, baik dari golongan orang-orang Rosikh ilmunya maupun orang awam. Sedangkan hukum amali lahiriyah dapat dikembangkan melalui metode-metode baik metode Qiyasi, ta'wili maupun menerangkan hikmah-hikmah yang dicapai walaupun setiap ulama' berbeda hasil yang diperoleh dalam mengungkapkan rahasia hukum tersebut (Nurhadi: 2018; AshShiddieqy: 393). 
Sudirman M. Johan, Nurhdi, Akhmad Mujahidin, Ahmad Rofiq, Mawardi Muhammad Saleh; Konsep Hikmat Al-Tasyrî' sebagai Asas Ekonomi dan Keuangan Bisnis Islam Menurut Ali Ahmad Al-Jurjawi (1866-1961M) dalam Kitab Hikmat Al-Tasyrî’ Wa Falsafatuhu

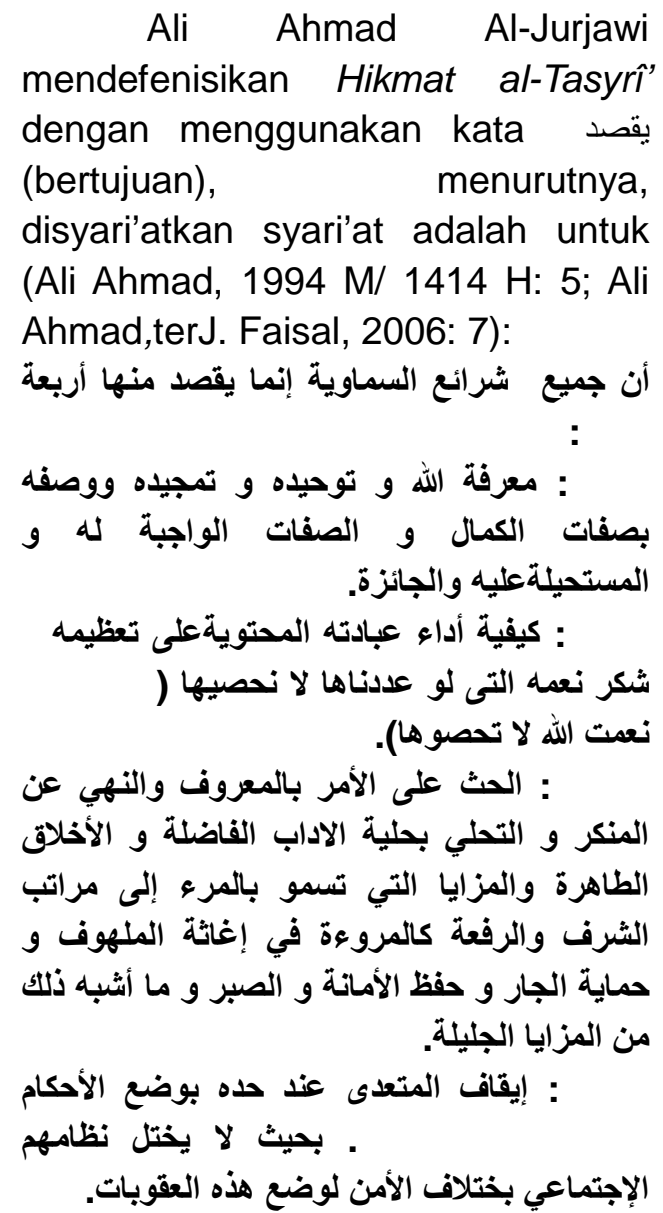

Dari ungkapan Al-Jurjawi di atas maka dapat peneliti simpulkan bahwa defenisi Hikmat al-Tasyri' (maqashid syariah) Al-Jurjawi menurut peneliti adalah:

حكمة التشريع: حكمة بالغة تبهر العقول وترتاح

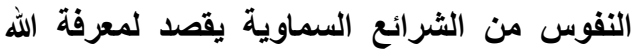
وتوحيده ومعرفة كيفية العبادته والمعاملات بوضع لئع ته المنكرومصلحات العباد في الانيا والاخرته.

Artinya: Hikmat al-Tsyri' adalah hikmah-hikmah yang menakjubkan dan mencengangkan akal pikiran serta memuaskan hati dari syaiat-syaiat agama samawi yang bertujuan untuk mengenal Allah dan mentauhidkanya dan mengetahui cara beribadah dan bermuamalah dengan menetapkan hukum-hukum yang diperlukan agar terlaksana amar ma'ruf nahi mungkar dan kemashlahatan hamba di dunia dan akhirat.

Ta'rif Maqashid Syariah menurut AdDahlawi dalam kitab Hujjatullah alBâlighah sebagaimana dikutip Yahya Sai'di dalam kitabnya Tauzhif Maqashid Syariah fi Fahmi al-Qur'an wa Tafsirihi adalah (Yahya Sai'di, t.th: 526):

$$
\begin{aligned}
& \text { مقاصد الثريعة: علم اسرار الاين, } \\
& \text { الاحكام ولمياتها(حقيقتها) } \\
& \text { خواص الاعمال نكاتها. }
\end{aligned}
$$

Artinya: Ilmu asrar agama (rahasiarahasia agama) yang membahas tentang hukumhukum yang berlaku dan asrar (rahasia) khusus tentang amal-amal dan keajaiabanya (Syah Wali, 2005: 22).

Maka inti teori maqashid Dahlawi adalah tentang pembagian maqashid menjadi maqashid ammah, khassah dan Juziyyah.

Ahmad al-Raisuni terminology tentang maqashid al-Syariah (Ahmad ar-Raisuni, 1992: 13):

مقاصد الثريعة هي الغايات التي وضعت الثريعة لأجل تحقيقها لمصلحة العباد.

Artinya: Maqashid syariah adalah tujuan-tujuan yang diletakkan syariat untuk merealisasikan kemaslahatan umat manusia (Ahmad al-Raisuni, 1995: 7).

Wahbah al-Zuhaily mendefinisikan maqashid al-Syariah (Wahbah, 1986: 1017):

مقاصد الثريعة هي الغايات والأهداف والنتائج والمعاني التي أتت بها الثريعة الغرَّاء، وأثبتتها 
Al-Fikra: Jurnal IImiah Keislaman, Vol. 17, No. 1, Januari - Juni, 2018 (147 189)

الأحكام الثرعية، وسنَتَ إلى تحقيقها وإيجادها والوصول إليها في كل

Artinya: Maqashid syariah adalah Makna-makna dan tujuan yang dititikberatkan dalam semua hukum atau sebagian besarnya atau ialah maksud dari syariat dan rahasiarahasia yang diletakkan oleh syari' dalam setiap hokum Wahbah, 1996: 1017).

Khalifah Babkrin Husain, mendefenisikan maqashid sama dengan Wahbah al-Zuhaili hanya saja ditambah dengan kalimat (Nurhadi: 2018):

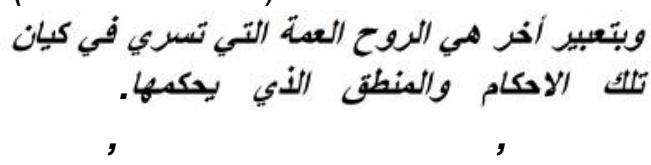

Artinya: Makna-makna dan tujuan yang dititikberatkan dalam semua hukum atau sebagian besarnya atau ialah maksud dari syariat dan rahasia-rahasia yang diletakkan oleh syari' dalam setiap hukum, ibarat yang lain yaiyu ruh umum yang mengalir pada nilai hukum, ungkapan hukumnya dan tercapai kekhususanya dan dibangun dari dasardasarnya dan terpenuhinya metode dasar pendapat hukumnya (Khalifah, 1421 H / 2000 M: 6).

'Alal al-Fasi mendefinisikan maqashid al-syariah (Allal Al-Fasy, 1993: 36):

بمقاصد الثريعة: الغاية منها، والأسرار التي وضعها الثارع عند كل حكم من أحكامها

Artinya: Maqashid al-Syariah adalah tujuan (umum) dari pemberlakuan syariat dan beberapa rahasia (khusus) yang terkandung dalam setiap produk hukumnya (llal bin Abdul, 1999 M).

Ibnu 'Asyur mengatakan maqashid al-Syariah al-'Ammah:

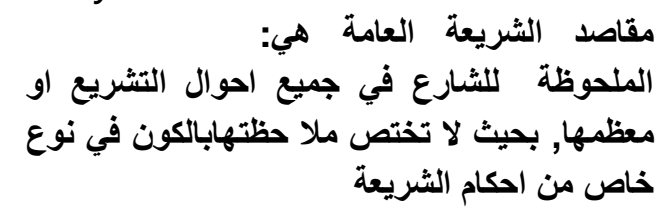

Artinya: Maqashid syariah ammah adalah memakmurkan kehidupan di bumi, menjaga ketertiban di dalamnya, senantiasa menjaga stabilitas kemaslahatan alam dengan tanggungjawab manusia menciptakan lingkungan yang sehat, berlaku adil dan berbagai tindakan yang dapat bermanfaat bagi lapisan seluruh penghuni bumi (Muhammad Thahir, 1996 M: 51).

Mwenurut Muhammad Al-Yubi, Maqashid Syariah adalah:

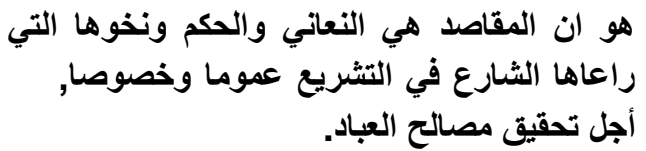

Artinya: Maqâshid syarî'ah adalah makna-makna dan hikmahhikmah yang telah ditetapkan oleh Allah dalam syariatnya baik yang khusus atau umum yang bertujuan untuk merealisasikan

kemaslahatan hamba (Muhammad Sa'adi, 1998: 35-37).

Menurut Yusuf al-Qardlawi dalam kitab fiqih maqashidnya (Nurhadi: 2018): 
Sudirman M. Johan, Nurhdi, Akhmad Mujahidin, Ahmad Rofiq, Mawardi Muhammad Saleh; Konsep Hikmat Al-Tasyrî' sebagai Asas Ekonomi dan Keuangan Bisnis Islam Menurut Ali Ahmad Al-Jurjawi (1866-1961M) dalam Kitab Hikmat Al-Tasyrî’ Wa Falsafatuhu

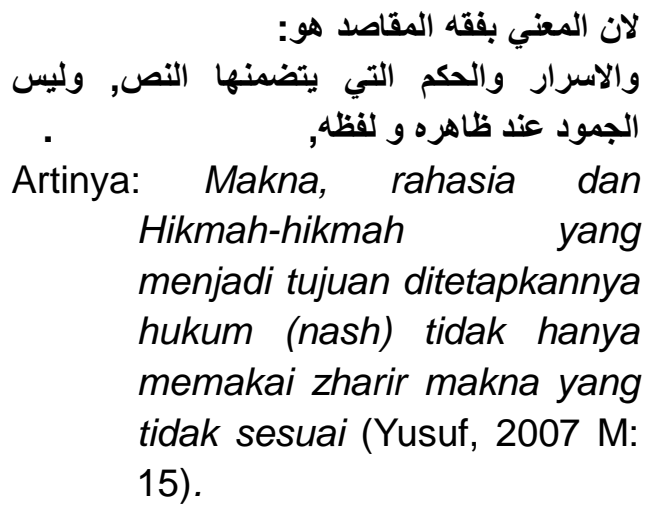

Definisi maqashdi ulama klasik, seperti Izuddin dan Syathibi (Izuddin, 2000 M: 314; Ibu Taimiyah: 1398; Ibnu Taimiyah: 54; Umar: 16-17):
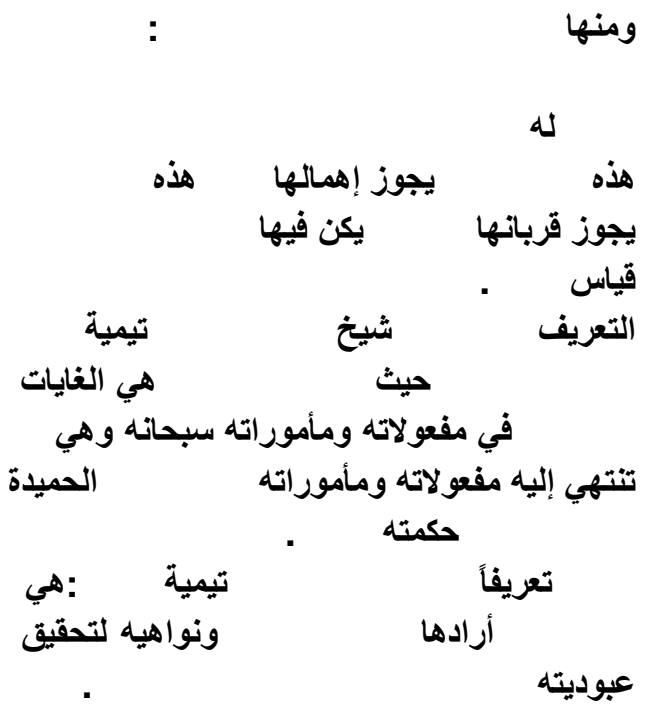

Abdul Wahhab Khallaf, seorang pakar ushûl fiqh, menyatakan bahwa nash-nash syarîah itu tidak dapat dipahami secara benar kecuali oleh seseorang yang mengetahui maqâshid syarî’ah (tujuan hukum) (Abd al-Wahab, 1968: 198).

Definisi maqashid syariah (hikmah tasyri') yang peneliti tawarkan sebagai penemuan menurut peneliti adalah:

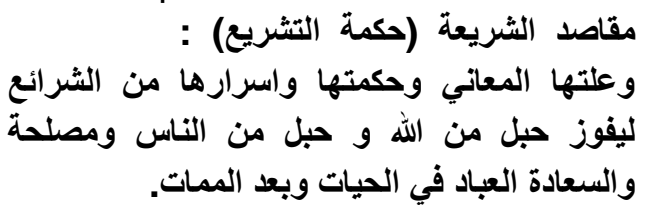

Artinya: Maqashid syariah (hikmah tasyri') adalah hujjah yang kuat dan illatnya yang penuh makna-makna dan hikmahhikmah dan rahasia-rahasia dari syariat-syariat untuk mencapai keberhasilan hubungan baik dengan Allah dan Manusia dan kemashlahatan dan kebahagiaan hamba dalam hidupnya dan sesudah mati (akhirat).

Pengertian Hikmat al-Tasyrî' yang dikemukakan oleh Ali Ahmad al-Jurjawi diatas sedikit berbeda dengan pengertian Maqâshid Syarîah secara umum dari ulama lainya, menurutnya Hikmat al-Tasyrî adalah merealisasikan kemaslahatan atau menolak kemudharatan, namun intinya sama, yaitu hikmah dan makna tentang syariat untuk kemashlahatan umat (Nurhadi: 2018; Sabariyah: 103). Pengertian Hikmat al-Tasyrî' yang dikemukakan al-Jurjawi lebih aplikatif. Ada empat aspek yang menjadi fokus perhatian Ali Ahmad al-Jurjawi ketika menjelaskan Hikmat al-Tasyrî', keempat aspek tersebut di antaranya:

1) Memperkokoh keyakinan kepada Allah swt (tauhid) (Suryan, 2008: 40) (maqâshid wahîdiyah/khalîqiyah/tau hîdiyah).

2) Merealisasikan keimanan kepada Allah swt dalam bentuk melaksanakan ibadah (syari'at) (maqâshid 'Ibâdiyah). 
Al-Fikra: Jurnal IImiah Keislaman, Vol. 17, No. 1, Januari - Juni, 2018 (147 189)

3) Melakukan amar makruf nahi mungkar dan berakhlak mulia (maqîshid khulûqiyah).

4) Melakukan tindakan preventif/pencegahan kemungkaran dan kezaliman (maqâshid waqâ'iyyah).

Berdasarkan penjelasan di atas, tujuan utama dari disyariatkannya hukum kepada manusia adalah agar menghambakan dirinya kepada Allah swt dalam bentuk beribadah kepadaNya. Ibadah itu sendiri adalah tujuan Allah swt menciptakan jin dan manusia (Depag RI: 862) dan tujuan di balik rahasia penciptaan langit dan bumi (Depag RI: 947).

Dari empat defenisi Hikmat al-Tasyrî' yang dikemukakan oleh alJurjawi di atas apabila dikaitkan dengan posisi manusia sebagai makhluk sosial di bumi ini dapat dibagi dalam dua kelompok besar:

1) Tujuan pertama dan kedua: Mentauhidkan Allah swt dan membuktikannya dengan ibadah, adalah dua hal yang sangat terkait dengan hubungan manusia dengan Allah sang khalik (Depag RI: 460).

2) Tujuan ketiga dan keempat: Amar makruf nahi mungkar dan pencegahan adalah dua hal yang terkait dari hubungan manusia dengan manusia (Depag Rl: 156).
Kedua kelompok besar dalam Hikmat al-Tasyrí' al-Jurjawi ini, bersumber dari firman Alah swt dalam surah al-Imran ayat 112 :



Artinya: Mereka diliputi kehinaan di mana saja mereka berada, kecuali jika mereka berpegang kepada tali (agama) Allah dan tali (perjanjian) dengan manusia (Departemen Agama RI, 2002: 65).

Ayat diatas dapat dibagi menjadi dua kelompok, yaitu:

Tabel I

Qawâid Maqâshidiyah dengan Maqâshid Syariah

dan Hikmat al-Tasyri' dengan Mashlahah

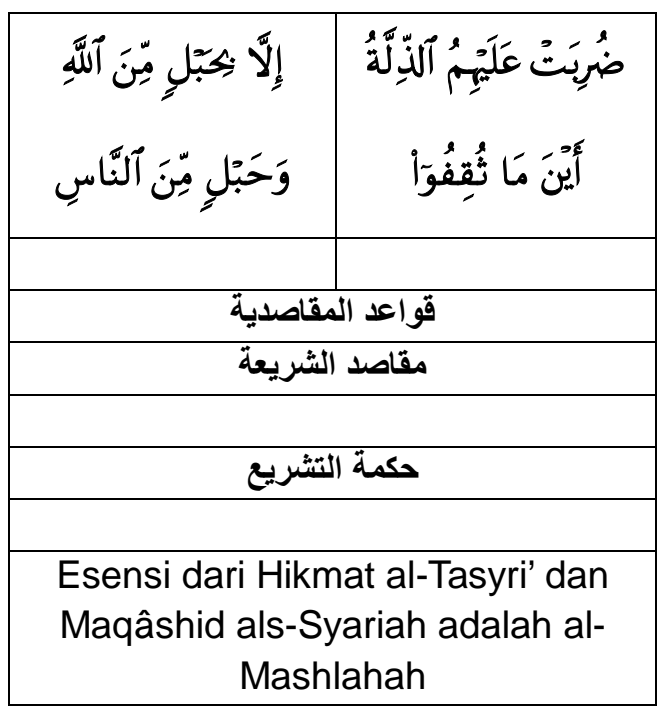

Konsep (kerangka) berpikir Ali Ahmad al-Jurjawi ini sesungguhnya adalah konsep dasar memahami Islam (Nurhadi: 2018; Sabariyah: 143-145). Aqidah, Ibadah dan Akhlak adalah tiga hal utama 
Sudirman M. Johan, Nurhdi, Akhmad Mujahidin, Ahmad Rofiq, Mawardi Muhammad Saleh; Konsep Hikmat Al-Tasyrî' sebagai Asas Ekonomi dan Keuangan Bisnis Islam Menurut Ali Ahmad Al-Jurjawi (1866-1961M) dalam Kitab Hikmat Al-Tasyrî’ Wa Falsafatuhu

ajaran Islam yang mempunyai hubungan Interaktif tidak dapat dipisahkan satu dengan yang lain. Dalam kontek ini Islam di umpamakan sebatang pohon yang gambaran idealnya terdiri dari akar, batang dan buah. Aqidah sebagai akar, ibadah sebagai batang dan akhlak sebagai buah (Sabariyah: 106). Korelasi antara ketiga unsur Iman, Ibadah dan Akhlak ini secara Kausalitatif. Iman sebagai akar akan menumbuhkan Ibadah sebagai batang akan menghasilkan Akhlak sebagai buah. Dari perumpamaan ini terlihat bahwa aqidah memegang peran sentral bagi kelslaman seseorang (Nurhadi: 2018; Suryan, 2008: 38). Perumpamaan ini dapat di gambarkan dalam pohon Islam sebagai berikut: semua ibadah yang diperintahkan dan menjauhi semua perbuatan yang dilarang. Dengan satu tujuan ahir mampu membuat manusia butuh terhadap syari'at bukan karena ketakutan dan keterpaksaan (Nurhadi: 2018; Sabariyah: 145). Keunggulan konsep hikmat al-Tasyrî al-Jurjawi adalah lebih aplikatif dan sesuai dengan kemodrenan, yang mana manusia haus dengan motivasi beribadah, sehinnga hikmat al-Tasyrî' al-Jurjawi ini lebih aplikatif motivatif, diharapkan buah dari ibadah adalah amar ma'ruf nahi mngkar.

Sebagai perbandingan tentang konsep hikmat al-Tasyri' alJurjawi, peneliti memaparkan sedikit konsep maqashid syariah atau asrar ahkam Waliyullah Ad-Dahlawi dalam

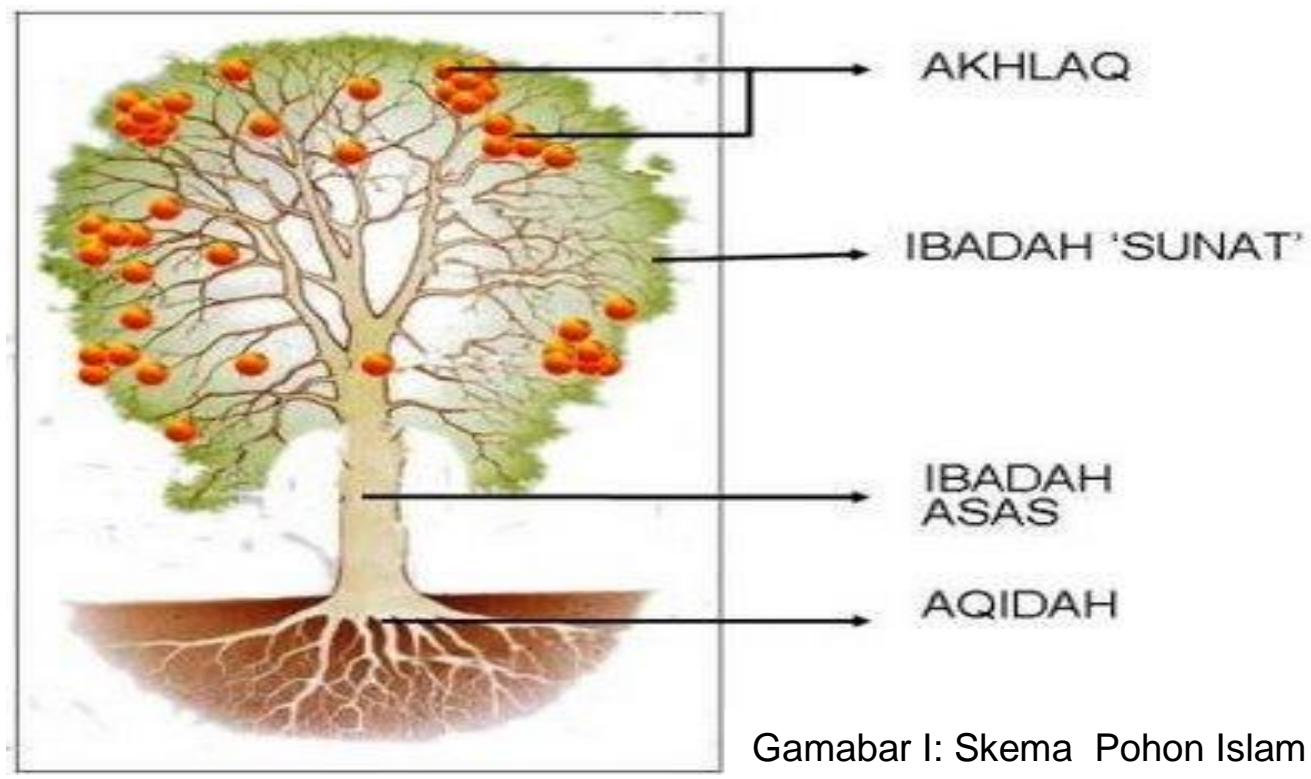

Metodologi al-Jurjawi dalam memahami hikmat al-Tasyrî' ini sangat relevan dengan kondisi kekinian, manusia haus dengan penjelasan syari'at yang dalam dan dapat memotivasi manusia dalam memahami dan mengamalkan
kitabnya
Hujjatullah
al-Baligha.
Menurut
Dahlawi
syari'at sebagaimana dipahaminya memiliki tujuan jelas yaitu kemaslahatan manusia, beliau menggunakan akhirat sebagai poin penjelasan atas 

189)

hubungan antara eksistensi duniawi dan akhirat. Baginya, syari'at di lihat sebagai sebuah desakan alami kemanusiaan yang harus terjadi dalam sejarah sebagai entitas yang berasal dari kehendak Allah karena Allah ingin melindungi makhluknya, manusia dan yang lain, baik dalam kehidupan ini dan dari hukuman neraka. Melalui syari'at, Allah juga akan membalas tindakan individual di dunia dengan pahala yang tidak terbatas di akhirat dan dengan demikian proses perkembangan masyarakat Islam adalah memberi penjelasan dari Realitas Akhirat. Hal ini merupakan konsekuensi alami dari utilitas besar atas tanggung jawab di dunia ini. Dahlawi mencontohkan syari'at shalat, zakat dan puasa sebagai berikut: "kewajiban shalat disyariatkan untuk mengingat Allah dan berkomunikasi secara langsung dan pribadi dengan-Nya, sebagaimana firman Allah swt., "Dirikanlah sholat untuk mengingatku" (Depag RI: 477) juga sebagai tindakan persiapan untuk kelak memandang Tuhan swt. di kehidupan yang akan datang". Zakat disyariatkan agar manusia terhidar dari sifat pelit yang hina dan agar kebutuhan orang miskin terpenuhi. Puasa disyariatkan agar setiap muslim menyadari kerendahan dirinya dan agar mereka senantiasa menundukkan jiwa" (Syah Wali, 2005: 27). Syari'at sholat, zakat, puasa, haji, kisas, huhud dan jihad dipahami oleh Dahlawi tidak hanya berdimensi ketuhanan saja (kesholihan individu) selain sebagai bentuk ketundukan makhluk kepada penciptanya sehingga memperoleh balasan kebiakan di akhirat, tetapi juga berdimensi sosial (kesholihan sosial). Pemahaman yang semacam ini menunjukan peran akal/ nalar dalam memahami syari'at sehingga dapat diketahui rahasia-rahasianya (Syah Wali, 2005: 28).

Imam Dahlawi menjelaskan bahwa sesungguhnya pembebanan kewajiban-kewajiban agama memiliki makna batin (rahasia). la mendasarkan pada surat al-Ahzab 33: 72-73 (Syah Wali, 2005: 53-54), yang artinya: "Sesungguhnya kami telah mengemukakan amanat kepada langit, bumi dan gununggunung, maka semuanya enggan untuk memikul amanat itu dan mereka khawatir akan mengkhianatinya, dan dipikullah amanat itu oleh manusia. Sesungguhnya manusia itu Amat zalim dan Amat bodoh. Sehingga Allah mengazab orang-orang munafik laki-laki dan perempuan dan orang-orang musyrikin laki-laki dan perempuan; dan sehingga Allah menerima taubat orang-orang mukmin laki-laki dan perempuan. dan adalah Allah Maha Pengampun lagi Maha Penyayang" (Depag RI: 680).

Bagi umat Islam, Allah mewajibkan shalat, ibadah haji, puasa, zakat dan kewajibankewajiban lainnya. Kewajibankewajiban tersebut memiliki makna batin (rahasia atau hikmah) yang bertujuan untuk kebahagiaan dan kemaslahatan bagi umat Islam itu sendiri, demikian juga pendapat Dahlawi (Syah Wali, 2005: 27-28). Mencari sebab-sebab perbedaan pendapat ulama dalam memahami 
Sudirman M. Johan, Nurhdi, Akhmad Mujahidin, Ahmad Rofiq, Mawardi Muhammad Saleh; Konsep Hikmat Al-Tasyrî' sebagai Asas Ekonomi dan Keuangan Bisnis Islam Menurut Ali Ahmad Al-Jurjawi (1866-1961M) dalam Kitab Hikmat Al-Tasyrî’ Wa Falsafatuhu

teks syar'i dan mencari makna batin yang terdapat dalam ketentuan syari'at merupakan metode Dahlawi dalam melakukan istinbat al ahkam. Untuk menyikapi hadits-hadits yang berbeda, Dahlawi menggariskan bahwa prinsip dasar yang di gunakan adalah berusaha mengamalkan semua hadis kecuali jika terdapat pertentangan yang menghalangi pengamalan hadishadis tersebut. Pada dasarnya tidak mungkin ada pertentangan antara hadis-hadis kecuali dari sudut pandang kita. Dengan demikian, jika ada dua hadis yang tampaknya bertentang tentang suatu perbuatan Nabi, misalnya seorang sahabat mengatakan bahwa Nabi saw mengerjakan sesuatu dan sahabat lain mengatakan bahwa Nabi saw mengerjakan sesuatu yang lain, maka sesungguhnya tidak ada pertentang antara keduanya. Kedua perbuatan tersebut bisa dianggap sebagai perbuatan yang dibolehkan, yakni jika keduanya termasuk kebiasaan umum dan tidak berkaitan dengan ajaran agama. Pemahaman lain, bisa jadi bahwa salah satu dari kedua perbuatan itu dianjurkan (mustahab) sedangkan yang lain kebolehan (mubah), karena perbuatan pertama menghasilkan kedekatan kepada Allah sedangkan yang kedua tidak. Jika keduanya termasuk perbuatan ibadah, maka salah satu perbuatan itu mungkin dianjurkan (nadb) atau diwajibkan dan perbuatan lainnya termasuk pelengkap atau penyempurna bagi perbuatan lain (Nurhadi: 2018; Syah Wali: 238).

Dari kedua teori maqashid syariah kedua tokoh (al-Jurjawi dan al-Dahlawi), keduannya mempunyai kemiripan tentang hikmat al-Tasyri dan Asrar al-Ahkam, terwujud dalam kemashlahatan hamba dunia dan akhirat. Teori keduanya juga mengarah kepada ayat 112 surah alImran di atas, yang intinya menjadi dua kelompok, yaitu:

Tabel II

Skema Qawaid dan Maqâshid Syariah dan Hikmat al-Tasyri' Serta Asrar Al-Ahkam dengan Mashlahah

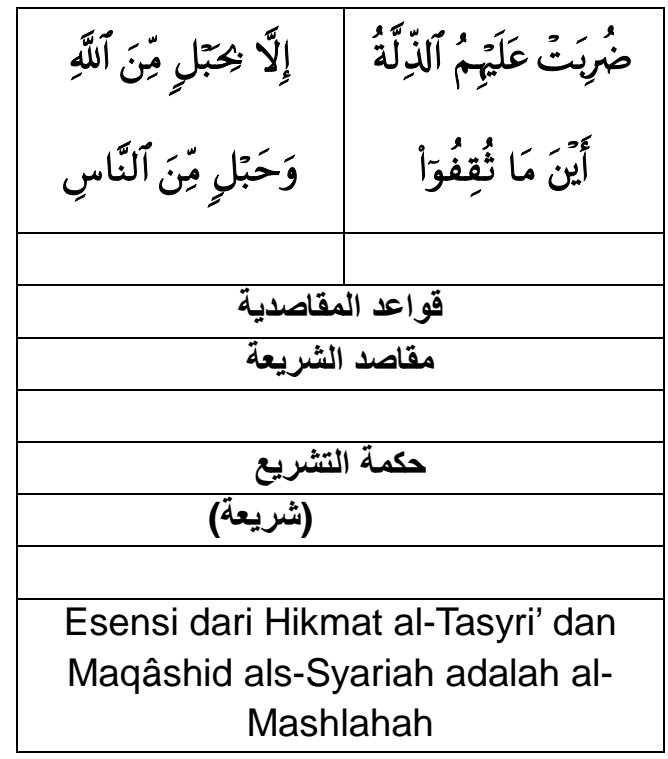

Teori keduanya juga akan integral dengan teori gelombang zikir makrifatullah: 


\section{Gambar III: Skema Toeri Gelombang Zikir Makrifatullah}

Makrifat

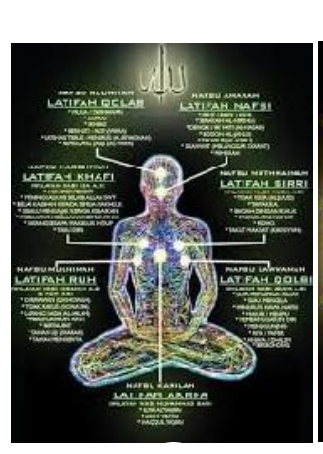

1

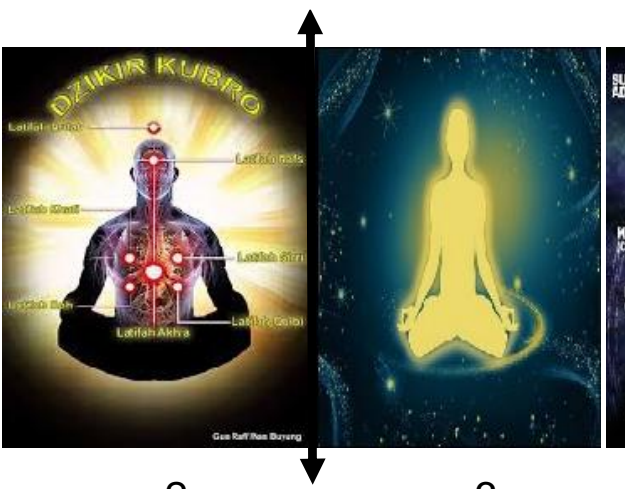

2
3

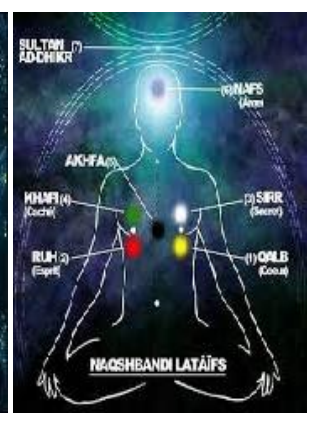

4

Syariat

Proses keempat gelombang tersebut sampai pada tatanan hablum minallah dan hablum minnas, lalu

Hikmah tasyri' adalah hubungan pertikal antara manusia dengan penciptanya yang tentu tidak akan terlepas dari sesamanya, artinya maqashid syariah dari suatu syariat semata-mata untuk mengendalikan badan dari hawa nafsu, dengan cara perhalus jiwa dengan mengisi jiwa dengan zikir dan ingat kepada segala nikmat Allah, dengan demikian akan menentramkan ruh dalam jiwa dan raga, maka akan sampailah pada titik akhir yaitu makrifatullah dengan segala kemaha sucianya dan kebijaksanaannya yang penuh dengan hikmah (akhlak) sehingga tercapai dan terbuka pintupintu mukasyafah (tirai rahasia) alam semesta. Jika di hubungkan dengan kegiatan ekonomi akan tergambar dalam skema sebagai berikut (Nurhadi: 2018): ekonomi bisnis (muamalah iqtishadiyah) dengan kaedah ushul fiqih tentang muamalah sebagai berikut: melahirkan hikmh-hikmah akhlak yang mulia kepada sesama dan sang khalik. Skemanya akan terlihat sebagai berikut (Nurhadi: 2018):

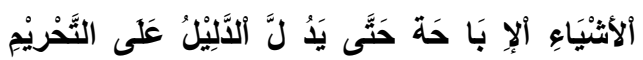
maksudnya adalah asal pada tiap sesuatu (muamalah) adalah boleh sehingga ada dalil yang menunjukkan keharamannya. Didukung dengan kaedah sejenis berikut:

maknanya asal pada setiap muamalah adalah halal. Inti dari kaedah ini adalah kemashlahatan hamba dunia akhirat (Nurhadi: 2018).

Menurut peneliti teori integral gelombang zikir makrifatullah dengan kemashlahatan hamba dalam kelapangan (kemubahan/kebolehan) hukum muamalah ekonomi kecuali ada dalil yang mengharamkanya sebagai mana sejalan dengan kaedah fiqih dan usul fiqih di atas, maka menurut peneliti hikmah tasyri' perspektif alJurjawi sebagai asas ekonomi dan keuangan dalam bisnis Islam, terletak pada kemashlahatan hikmah 
Sudirman M. Johan, Nurhdi, Akhmad Mujahidin, Ahmad Rofiq, Mawardi

Muhammad Saleh; Konsep Hikmat Al-Tasyrî' sebagai Asas Ekonomi dan

Keuangan Bisnis Islam Menurut Ali Ahmad Al-Jurjawi (1866-1961M) dalam Kitab Hikmat Al-Tasyrî' Wa Falsafatuhu

ihya al-Mawat (menhidupkan tanah yang kosong). Secara filosofis ihyau al-mawat adalah upaya menghidupakan lahan mati/kosong yang tidak berproduksi/bermanfaat menjadi berproduksi sehingga menghidupkanya atau memproduktifkanya adalah kemashlahatan dan banyak manfaatnya bagi banyak orang/manusia teori ekonomi menyatakan bahwa kegiatan ekonomi merupakan upaya memproduksi, mendistribusi dan menkonsumsi untuk kebutuhan hidup manusia. Sedangkan dalam ekonomi keuangan bisnis kontemporer kemaslahatan terletak dalam berinovasi produk ekonomi dan keuangan bisnis syariah maka hikmah ihyau al-mawat al-Jurjawi adalah konsep dasar dalam mewujudkan nilai-nilai ekonomi, keuangan dan bisnis syariah menurut peneliti di gambarkan dalam teori gelombang zikir makrifat dari empat konsep (syariat, thariqat, hakikat dan makrifat) dalam lingkup hablumminallah dan hablumminnas. Skemanya lihat dalam skema sebagai berikut (Nurhadi: 2018):

\subsection{Esensi Hikmat Al- Tasyri'}

Ada beberapa kata yang ada kaitannya dengan kata Hikmat alTasyri' yang sering dijumpai, menurut Nuruddin al-Khadimi menyatakan ada banyak padanan kata dari hikmah tasyri' atau maqashid syariah, dengan ungkapanya (Nuruddin: 26; Umar Muhammad: 17):
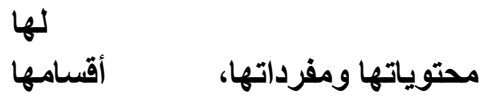

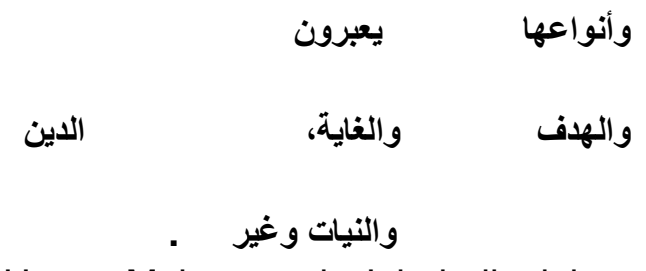

Umar Muhammad Jabahuji dalam kitabnya Maqashid Syariah al-Islami hanya membahas empat macam saja yaitu, illat, hikmah, mashlahah dan munasbah serta makna (Umar Muhammad: 22-28). Namun sasaran penulisan penelitian ini lebih ditampilkan pada beberapa pengertian kata tersebut, seperti (Muhammad bin Farhun, 1301H: 8; Wahbah, 1986: 646; Ahmad alRaisuni: 18). 3; Nurizal Ismail, 2014: 3-5):

a. Illat.

Dalam ushul fiqh permasalahan hikmah dibahas ketika ulama ushul fiqih membahas salah satu metode ijtihad (AlGhazali, 1324 H: 350), yaitu membahas sifat-sifat yang dijadikan illat hukum pada pembahasan qiyas (Muhammad Abu Zahrah, t.th: 218). Secara etimologi 'lllat berarti sesuatu yang dapat mengubah sesuatu yang lain (Nurhadi: 2018; Ensiklopedi Hukum Islam: 696).

Sedangkan Illat secara istilah atau terminologi adalah:

الظاهر المنضبط المناسب للحكم

Artinya: Illat ialah suatu keadaan (sifat/factor) yang konkrit (zhahir), dapat diukur (mundhabith), mempunyai relevansi dengan hukum (munasib), yang keberadaannya diduga berat menjadi alasan ditetapkannya suatu hukum, 
bila keadaan (sifat) itu tidak ada, maka hukumpun tidak ada (Musthafa, 1981: 13; Zakiyuddin, $1964 \mathrm{H}$ : 132).

Ulama ushul fiqh menyatakan bahwa apabila disebut dengan illat, maka yang dimaksud adalah:

1) Hikmah yang menjadi motivasi dalam menetapkan hukum, berupa pencapaian kemaslahatan atau menolak kemafsadatan.

2) Sifat zhahîr yang dapat diukur sejalan dengan suatu hukum dalam mencapai kemaslahatan, baik berupa manfaat bagi manusia maupun menolak mafsadat (Huderi Beik, 1988: 298). Pengertian "sifat yang zhahîr" adalah suatu sifat yang terdapat dalam suatu hukum yang dinalar oleh manusia. Sedangkan "bisa diukur" adalah berlaku umum untuk setiap individu (Nurhadi: 2018; Nasrun, 1996: 79).

Mayoritas ulama: Abu Hanifah (9-150 H), Imam Malik (93$179 \mathrm{H})$, Imam al-Syafi'i (150-241 H) dan Ahmad bin Hanbal (164- $241 \mathrm{H}$ ) menggunakan illat untuk menetapkan hukum persoalan yang tidak disebutkan secara tekstual dalam al-Qur'an dan as-Sunnah Nabi saw (Al-sarakhsi, $1372 \mathrm{H}$ : 118119; al-Syathibi, t.th: 92-100; Imam al-Syafi'i, t.th: 476-286; Ibnu alQayyim, t.th: 130-220). Pencarian 'illat umumnya didominasi dengan menggunakan ra'yu. Porsi penggunaan ra'yu berbeda-beda antara seorang ulama mujtahid dengan yang lainnya (Sabariyah: 86).

\section{b. Sabab.}

Dalam kajian usul fiqih sabab termasuk dalam pembagian hukum Wadh'î (sabab, syarat dan mani'). Fungsi dari hukum wadh'î itu sendiri adalah sebagai berlakunya hukum taklify. Hukum taklify baru akan mempunyai pengaruhnya menurut hukum Syara' apabila terpenuhi hukum wadh'i. Oleh sebab itu disatu sisi ada hukum taklîfi yang merupakan tuntunan Allah swt, disisi lain ada hukum wadh'î. Hukum taklîfy bisa diterapkan secara benar didalam kenyataan kehidupan. Hubungan yang harmonis antara hukum taklîfy dan wadh'î mengakibatkan sahnya perbuatan, sedangkan keduanya sangat memiliki hubungan sebagai penyebab batalnya perbuatan (Nurhadi: 2018; Sabariyah: 87).

Sabab ( ) yang didalam bahasa Indonesia disebut sebab, dalam kamus fiqih dijelaskan bahwa sebab adalah:

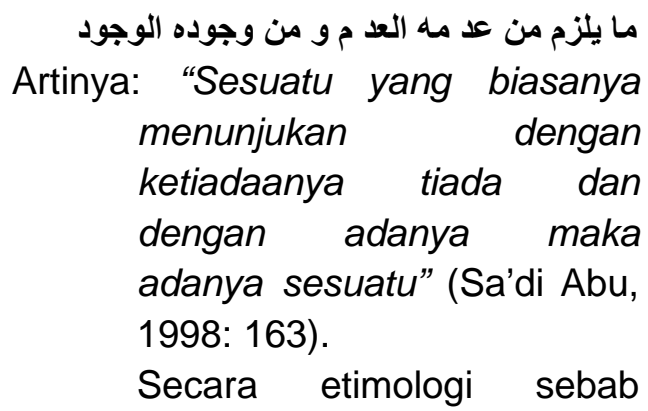
adalah sesuatu yang memungkinkan dengannya sampai pada suatu tujuan (Amir, 2009: 395). Dari kata inilah dinamakan "jalan" itu sebagai sebab, karena "jalan" bisa menyampaikan seseorang kepada tujuan (Abu Hamid: 517; Abu Hamid: 
Sudirman M. Johan, Nurhdi, Akhmad Mujahidin, Ahmad Rofiq, Mawardi

Muhammad Saleh; Konsep Hikmat Al-Tasyrî' sebagai Asas Ekonomi dan

Keuangan Bisnis Islam Menurut Ali Ahmad Al-Jurjawi (1866-1961M) dalam Kitab Hikmat Al-Tasyrî’ Wa Falsafatuhu

23). Secara terminologi Imam alAmidi mendefinisikan sebab:

الوصف الظاهر المنضبط الذي جعله الثارع أمرة

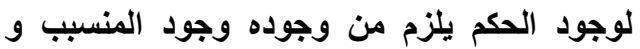

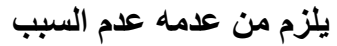

Artinya: "Sesuatu yang jelas, dapat diukur yang dijadikan syari' sebagai tanda adanya hukum; lazim dengan adanya tanda itu dieterima akal adanya hukum dan dengan tidak adanya tidak ada hukum " (Al-

Amidi,1971M/1391H: 71).

Dari defenisi di atas terdapat dua prinsip, yaitu sebab tidak dengan sendirinya berkedudukan sebagai sebab melainkan ditetapkan syari', menjadi sandaran adanya hukum (Muhammad al-Ghazali: 283; Abu Hamid: 23). Kedua sebab tidak berpengaruh terhadap adanya hukum taklif; sebab itu hanya sebatas pertanda nyata adanya hukum (Muhammad al-Ghazali: 177178; Abu Hamid: 23).

\section{c. Syarat.}

Secara etimologi syarat adalah alamat atau tanda (Sa'di Abu: 192). Secara terminologi syarat adalah (Saifuddin al-Amidi, t.th: 121):

ما يتوقف وجود الحكم وجودا شرعيا على وجود ويكون خارجا عن حقيقته و يلزم من عدمده عدي عدم وجدم

Artinya: "Sesutau yang tergantung padanya keberadaan hukum syari' dan ia berada di luar hukum itu sendiri, yang ketiadaanya hukumpun tidak ada"

Terdapat hubungan yang erat antara syarat dengan sebab. Syarat merupakan penyempurna bagi sebab, apabila ada sebab dan syarat tidak terpenuhi maka hukum tidak ada. Sebagai contoh, akad nikah merupakan sebab bagi halalnya hubungan suami istri, tetapi akad itu harus memenuhi syarat adanya dua orang saksi dan mahar disamping akad yang dilakukan oleh wali dan laki-laki, begitu juga dengan pembunuhan menjadi sebab hukuman qishâs, akan tetapi qishâs baru bisa dilaksanakan apabila memenuhi syarat pembunuhan itu dilakukan dengan sengaja dan dengan permusuhan (Nurhadi: 2018; Sabariyah: 91).

Perbedaan antara sebab dan syarat adalah syarat tidak mengharuskannya adanya hukum. Adanya whudu' tidak mewajibkan adanya sholat, adanya saksi tidak mewajibkan adanya pernikahan. Akan tetapi sabab mengakibatkan adanya hukum kecuali ada mâni' atau penghalang (Sabariyah: 91).

\section{d. Mashlahah}

Kata mashahat satu makna dengan kata mashalih, kata mashlahah kebalikan dari makna mafsadah, maka mashlahah sesuatu perbuatan yang membawa manfaat (Ibnu Munzir: 374; Kamus Muhid: 229; Mu'jam Wasith: 520). Terminology ini juga diungkapkan Imam Gazali, yaitu memelihara tujuan dari syariat (Imam Gazali: 416-417). Menurut Ahmad Alyu Husein Tha'i mashlahah adalah manfaat yang harus di jaga dan mafsadat yang harus di abaikan yang dijadikan syariat hukum dan nash yang menunjukkanya atau lainya (Ahmad Alyu Husein, 2008 M: 21). Hubungan antara mashlahah 
dengan masqshid adalah samasama tujuan dari syariat, ini pendapat Gazali bahwa mashlahah menjaga maqashid syariah, sedangkan tujuan syariat menurutnya menjaga lima macam, yaitu: menjaga agama, jiwa, akal, keturunan dan harta. Kelimanya disebut ushulu khamsah, aslinya adalah mashlahah (Imam Gazall: 416-417).

\section{e. Munasabah}

Makna bahasa adalah berhadapan, berdekatan dan bersama atau bersekutu (Ibnu Munzir: 119; Kamus Muhid: 137; Tajul arus: 265). Terminologinya sifat nyata yang dapat diterima akal dan sistematika hukum yang mendatangkan mashlahah sebagai tujuanya dan menolak mafsadat (Amidi: 333; Umar Muhammad: 27). Menurut Imam Gazali sejalan dengan makna dan illat dalam pandangan kemashlahatan hukum (Imam Gazali: 146; Umar Muhammad: 27). Menurutnya juga kata munasabah itu keseuaianya dengan maqashid syariah menurut ulama ushul yang pada tujuanya adalah kemashlahatan (Imam Syatibi: 53; Umar Muhammad: 28).

\section{f. Makna}

Kata makna menurut sebagian ulama pengganti dari kata syariah, ahkam mashalih dan maqashid. Tidak sama para ulama dalam menyikapi masalah ini, jika dikatakan disyariatkan ini hukum artinya ini makna, maksudnya tujuan hukum, inilah inti dari syariat itu sendiri. Sebagaimana para ulama menggunakan kata makna ganti dari illat hukum (Ibnu Taimiyah: 56; Umar Mahmud: 28).

\subsection{Subtansi Hikmat Al- Tasyri' dalam Usul Fiqih}

Membahas hikmat al-Tasyri' atau tujuan dari pensyariatan Hukum Islam berarti mengkaji secara mendalam maksud Syari' (Muhammad Abu, 1985; Abd alWahhab Khallaf, 1978: 96) dalam alQur'an dan as-Sunnah. Pembahasan ini sangat penting dalam hukum Islam dan mendapat perhatian ulama serta pakar hukum Islam. Sebagian ulama menempatkannya dalam bahasan ushul fiqih, sebagian yang lain menyebutnya dengan fiqih maqâshid syarîah dan ulama lain membahasnya sebagai bahasan tersendiri serta diperluas dalam filsafat hukum Islam (Nurhadi: 2018; Amir, 2009: 119).

Hikmat al-Tasyrî' atau dalam ibadah disebut assâr ibadah meliputi kajian tentang kehendak dari lafazlafaz al-Quran dan sunnah. Bila diteliti semua perintah dan larangan Allah swt dalam al-Qur'an, begitu juga dengan perintah dan larangan Rasul dalam Sunnah yang terumuskan dalam fiqih akan terlihat bahwa semuanya mempunyai tujuan. Semuanya mempunyai hikmah yang dalam yaitu sebagai rahmat bagi umat manusia. Ditegaskan oleh Allah swt dalam surat al-Anbiya' ayat 107:

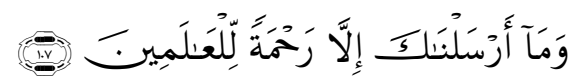

Artinya: "Dan Tiadalah Kami mengutus kamu, melainkan 
Sudirman M. Johan, Nurhdi, Akhmad Mujahidin, Ahmad Rofiq, Mawardi

Muhammad Saleh; Konsep Hikmat Al-Tasyrî' sebagai Asas Ekonomi dan

Keuangan Bisnis Islam Menurut Ali Ahmad Al-Jurjawi (1866-1961M) dalam Kitab Hikmat Al-Tasyrî’ Wa Falsafatuhu

untuk (menjadi) rahmat bagi semesta alam".

Redaksi ayat di atas sangat singkat, tetapi mengandung makna yang sangat luas. Hanya dengan lima kata yang terdiri dari 25 huruf mengandung empat hal pokok: 1), Rasul/utusan Allah swt dalam hal ini adalah Nabi Muhammad, 2). Yang mengutus yaitu Allah swt, 3). Yang diutus kepada mereka (al'âlamîn) serta 4). Risalah yang kesemuanya mengisyaratkan sifat-sifatnya yakni rahmat yang sifatnya sangat besar sebagaimana dipahami dari bentuk nakirah dari kata tersebut. Ditambah lagi dengan menggambarkan ketercakupan sasaran dalam semua waktu dan tempat (Nurhadi: 2018; M. Quraish, 2007: 519).

Dari ayat yang singkat di atas, dijelaskan bahwa Muhammad adalah Rahmat bagi sekalian alam. Kata Rahmatan adalah bentuk nakirah yang menunjukan Muhammad dalam segala hal, diri beliau, kepribadian, sikap, tingkah laku, pekataan, ajaran yang dibawa dan semua hal yang berhubungan dengannya adalah kebaikan (Nurhadi: 2018; Sabariyah: 93).

Ulama berbeda pendapat apakah kemaslahatan itu yang menjadi tujuan penetapan hukum syara'. Perbedaan pendapat ini diawali pada masalah aqidah (kalam) yang diawali ketika membahas tentang status perbuatan manusia (al-kasb). Ada dua pendapat yang berbeda dalam hal ini, kelompok Muktazilah berpendirian bahwa manusia berbuat dengan kemampuan (kudrat) yang dimilikinya sendiri, sedangkan kaum 'As'ariyah menyatakan bahwa perbuatan manusia dijadikan oleh Allah swt. Permasalahan ini berlanjut kepada perdebatan tentang kemampuan akal dalam mengenal baik buruknya suatu perbuatan. Kelompok Mu'tazilah menyatakan bahwa akal mampu mengenal dan membedakan nilai baik dan buruk dalam suatu perbuatan. Sebaliknya kalangan 'As'ariyah menolak dan berpendirian bahwa baik dan buruknya suatu perbuatan hanyalah dapat diketahui melalui ungkapan Nash (Nurhadi: 2018; Jabbar Sabil, 2009: 24).

Perdebatan mengenai apakah hukum yang ditetapkan Allah swt mempunyai maksud tertentu (kemaslahatan), sesungguhnya perdebatan tersebut semata-mata hanya perbedaan secara lafzi dan tidak mengakibatkan perbedaan secara praktis dalam penetapan hukum itu sendiri, karena semua pihak sepakat bahwa semua hukum yang ditetapkan Allah swt ada tujuannya dan itu adalah kemaslahatan umat manusia/hamba (Nurhadi: 2018; Amir, 2009: 220). Maka dapat disimpulkan bahwa ulama sepakat bahwa hikmah syarî'ah itu adalah kemaslahatan manusia dalam dua bentuk yaitu memperoleh kemaslahatan atau menolak kemudharatan atau dengan kaedah:

(menegakkan kemaslahatan atau menolak kerusakan).

Dalam pembahasan maqâshid al-syarî'ah yang menjadi bahasan utamanya adalah mengenai hikmah dan illat ditetapkannya suatu hukum 

189)

(Akhmad al-Raisuni, 1991: 67). Hikmah dan illat salah satu alat Bantu dalam menetapkan hukum yang berhubungan dengan maqâshid al-syarî'ah. Ada beberapa metode penetapan hukum yang erat kaitannya dengan maqashid syari'ah dengan menggunakan ijtihad yaitu ; Qiyâs (Muhammad Abu, t.th: 218), Istishân, Al-maslahah al-mursâlah, Saddu al-zarâî (Amir: 303).

Dalam qiyas kata illat dan hikmah memiliki peran penting dalam penetapan hukum karena biasanya setiap hukum akan diketahui illat dan hikmah pensyariatan hukum tersebut, sesuai dengan kaidah : الحكم يدور مع العلة وجودا ; Hukum itu tergantung dengan iilatnya, ada illat ada hukum, tidak ada illat tidak ada hukum. Hikmah muncul perdebatan, hikmah bisa mempengaruhi hukum/apakah hikmah dapat merubah suatu hukum sama halnya dengan illat? Dengan kata lain hikmah bisa menjadi illat hukum. Ulama ushul fiqih berbeda pendapat dalam hal ini menjadi tiga kelompok (Nurhadi: 2018; Sabariyah: 94-95):

Pertama: kelompok yang menolak menjadikan hikmah sebagai illat hukum (jumhur ulama antara lain Imam al-Amidi) dengan alasan hikmah dijadikan illat hukum maka akan berakibat berbedanya hukum dari illatnya, tidak dijumpai dalam kasus Syar'i dan hikmah adakalanya jelas dan adakalanya tidak jelas.

Kedua: kelompok yang membolehkan (Imam al-Gazali, alBaidawi, Fakhruddin ar-Razi dari kalangan ulama syafi'iyah, Ibnu
Taimiyah bermazhab Hambali, menyatakan bahwa hikmah bisa dijadikan illat hukum dengan alasan kebalikan dari yang menolak, menurut mereka hikmah itu jelas dan dapat diukur. Hikmah bagi sebahagian ulama ushul fiqih menurut mereka karena ketidakmampuan dan kurang jeli dalam menemukan hikmah saja. Hikmah tidak bisa dijadikan illat hukum maka menjadikan sifat yang sejalan atau sesuai dengan hukum (al-wasf al-munasib) juga tidak bisa dijadikan illat hukum. Illat mengandung kemaslahatan sekaligus menolak kemafsadatan. Menurut kesepakatan ulama mencapai kemaslahatan dan menolak kemafsadatan itulah hikmah, tidak ada alasan menolak hikmah menjadi illat hokum (Sabariyah: 95).

Ketiga: pendapat Imam alAmidi (570 H), Ibnu Hajib (646 H) ulama mazhab Maliki; hikmah yang jelas dan dapat diukur dapat dijadikan illat, sedangkan hikmah yang tidak jelas dan tidak dapat diukur tidak dapat dijadikan illat.

Perbedaan

pendapat mengenai hikmah dapat dijadikan illat hukum dijelaskan di atas dapat dinyatakan bahwa llat adalah sifat yang jelas dan ada tolak ukurnya, didalamnya terbukti adanya hikmah pada kebanyakan keadaan. Maka illat ditetapkan sebagai pertanda yang dapat ditegaskan dengan jelas adanya hikmah (Nurhadi: 2018; Fathurrahman, 1997: 4). Menurut Muslehuddin, hikmah merupakan inplisit didalam illat yang tidak dapat dipisahkan, karena hikmah tidak ada 
Sudirman M. Johan, Nurhdi, Akhmad Mujahidin, Ahmad Rofiq, Mawardi

Muhammad Saleh; Konsep Hikmat Al-Tasyrî' sebagai Asas Ekonomi dan

Keuangan Bisnis Islam Menurut Ali Ahmad Al-Jurjawi (1866-1961M) dalam Kitab Hikmat Al-Tasyrî’ Wa Falsafatuhu

jika illat tidak ada. Illat adalah dasar perbuatan, ia ada tanpa adanya hikmah, ia tidak dapat dianggap berasal dari hukum Allah swt yang maha bijaksana (Muslehuddin, 1980: 3; Sabariyah: 96).

Maslahat sama dengan manfaat baik dari segi lafadz maupun makna. Maslahat juga berarti manfaat atau sesuatu pekerjaan yang mengandung manfaat. Menurut Imam al-Gazali maslahah adalah mengambil manfaat dan menolak kemudharotan dalam rangka memelihara tujuantujuan syara' (Abu Hamid, 1983: 286). Imam al-Gazali memandang bahwa suatu kemaslahatan harus sejalan dengan tujuan syara' sekalipun bertentangan dengan tujuan manusia, karena kemaslahatan manusia tidak selamanya didasarkan kehendak syara' bahkan karena hawa nafsu, yang menjadi patokan kemaslahatan tersebut adalah kehendak dan tujuan syara' bukan kehendak dan tujuan manusia. Tujuan syara' yang harus dipelihara itu adalah; agama, jiwa, akal, keturunan dan harta.

Penyempurnaan konsep maslahah yang dikemukakan oleh Imam al-Gazali ini dilakukan oleh imam al-Syatibi dengan konsep maqâshid al-syarî̀ah. la menambahkan bahwa kemaslahatan yang harus dijaga tersebut tidak dibedakan antara kemaslahatan dunia maupun kemaslahatan akhirat. Kemaslahatan tersebut bertujuan untuk memelihara kelima tujuan syara' termasuk dalam konsep maslahah. Oleh karena itu kemaslahatan dunia yang dicapai harus bertujuan untuk kemaslahatan akhirat (Nurhadi: 2018; Sabariyah: 97).

Para ahli Ushul Fiqih
mengemukakan pembagian maslahah dilihat dari beberapa pandangan atau segi, yaitu: pertama: dilihat dari kualitas dan kepentingan maslahah terbagi tiga: maslahah darûriyah, hajîyah dan tahsîniyah. Kedua: kemaslahatan dilihat dari kandungan maslahah terbagi dua maslahah alammah dan maslahah al-khassah. Ketiga: Maslahah dilihat dari berubah atau tidaknya dibagi dua : maslahah al-stabitah (kemaslahatan yang bersifat tetap tidak berubah sampai akhir zaman. Maslahah Muthaqaiyarah (kemaslahatan yang berubah-ubah sesuai dengan perubahan tempat dan subjek hukum keaslahatan yang berkaitan dengan permasalahan muamalah dan adat kebiasaan. Keempat: dari segi keberadaan maslahah menurut syara' terbagi tiga : maslahah almu'tabarah (kemaslahatan yang didukung oleh syara' atau ada dalil khusus yang menjadi dasar bentuk dan jenis kemaslahatan tersebut). Maslahah al-mulqhah yaitu kemaslahatan yang ditolak oleh syara', karena bertentangan dengan syara'. Maslahah al-mursâlah yaitu kemaslahatan yang keberadaannya tidak di dukung syara' dan tidak pula dibatalkan/ditolak syara' melalui dalil yang rinci (Nurhadi: 2018; Nasrun: 115-119). Imam as-Syatibi sebagaimana yang dikutip oleh Yusuf al-Qardawi menjelaskan bahwa ibadah itu memiliki maksud asli dan maksud sekunder. Maksud 
Al-Fikra: Jurnal IImiah Keislaman, Vol. 17, No. 1, Januari - Juni, 2018 (147 189)

asli adalah semata-mata menuju Allah swt dengan tujuan tunduk, taat, mencintai dan menuju kepada Allah swt dalam setiap kondisi. Kemudian diikuti dengan bukti berupa beribadah untuk mendapatkan derajat diahirat atau menjadi kekasih Allah swt. Sedangkan maksud sekunder dalam ibadah adalah seperti meluruskan diri dan mendapatkan keutamaan (Yusuf, 2007: 209). Abdul Majid Najjar mengemukakan pembagian maqâshid al-syarî'ah yang ditinjau dari beberapa aspek yaitu (Abdul Majid, 2006: 36-49):

1) Aspek Kekuatannya dalam penetapan hukum, terbagi kepada tiga;
a. Maqâshid
Qath'iah
(tujuan pasti).
b. Maqâshid Dzanniyah (tujuan yang tidak pasti).
c. Maqâshid Wahmiyah (tujuan yang diragukan).

2) Aspek Fokusnya terbagi kepada tiga;
a. Maqâshid Kullîyah (tujuan global/keseluruhan).
b. Maqâshid Nau'ilyah (tujuan bagian).
c. Maqâshid Juzîyah (tujuan partikular).

3) Aspek Cakupannya maqâshid terbagi kepada dua;
a. Maqâshid 'Ammah (tujuan umum).
b. Maqâshid Khasshah (tujuan khusus).

4) Aspek Dasarnya, maqâshid terbagi kepada dua; b. Maqâshid Wasâil (tujuan antara).

5) Aspek Kekuatan mashlahahnya maqâshid terbagi kepada tiga;
a. Maqâshid Dharuriyah (tujuan sangat penting/pokok).
b. Maqâshid Hajîyah (tujuan yang penting).
c. Maqâshid Tahsiniyah (tujuan pelengkap).
Menanggapi pembagian maqâshid syarî'ah diatas, maka maqâshid syarî'ah menurut alJurjawi terbagi empat, sebagaimana telah disebutkan diawal bab ini, namun peneliti jelaskan secara sederhana, bahwa maqâshid syarî'ah (hikmat tasyri') ada empat serta padanan dengan kuliat alkhamsah atau ushulul khams, yaitu (Nurhadi: 2018):

1) Maqâshid wahîdiyah khâliqîyyah (tauhidiyah), artinya memperkuat keimanan kepada Allah swt (mentauhidkannya) bahwa Allah pencipta dan pengatur alam semesta. Ini kategori hifzu al-din.

2) Maqâshid 'Ibâdîyyah artinya merealisasikan keimanan dengan beribadah kepada Allah swt. Ini kategori hifzhu al-nafs.

3) Maqâshid khulûqîyyah artinya melakukan amar ma'ruf nahi munkar sebagai cerminan akhlak baik. Ini kategori hifzhu al-nasl wa al-mal. 
Sudirman M. Johan, Nurhdi, Akhmad Mujahidin, Ahmad Rofiq, Mawardi

Muhammad Saleh; Konsep Hikmat Al-Tasyrî' sebagai Asas Ekonomi dan

Keuangan Bisnis Islam Menurut Ali Ahmad Al-Jurjawi (1866-1961M) dalam Kitab Hikmat Al-Tasyrî’ Wa Falsafatuhu

4) Maqâshid waqâ'îyyah artinya melakukan tindakan

preventif/pencegahan kemungkaran dan kezaliman. Ini kategori hifzhu al-nas/ wa al-mal.

1.4. Analisis Hikmat Al$\begin{array}{lr}\text { Tasyrî' } & \begin{array}{r}\text { Asas } \\ \text { dan }\end{array} \\ \text { Kkonomi } & \begin{array}{l}\text { Keuangan } \\ \text { dalam }\end{array} \\ \text { Bisnis } & \text { Islam }\end{array}$ Menurut Ali Ahmad Al-Jurjawi

Ekonomi adalah bahasa umum dari seluruh kegiatan mu'âmalah iqtishâdiyah (transaksi), keuangan adalah bahagian dari kegiatan ekonomi, sedangkan bisnis adalah istilah lain dari bahasa ekonomi, karena bisnis lebih dikenal dalam istilah hukum (hukum bisnis). Sebab itu peneliti menganggap penting menjelaskan perbedaan ketiga istilah tersebut. Ekonomi Islam adalah sebagai suatu ilmu yang mempelajari perilaku manusia dalam usaha untuk memenuhi kebutuhan dengan alat pemenuhan kebutuhan yang terbatas dalam kerangka syariah (P3El, 2011: 14). Menurut Abdul Manan ilmu ekonomi Islam adalah ilmu pengetahuan sosial yang mempelajari masalahmasalah ekonomi masyarakat yang diilhami oleh nilai-nilai Islam (Muhammad Abdul, 1980: 3). Menurut Chapra ekonomi Islam adalah sebuah pengetahuan yang membantu upaya relisasi kebahagiaan manusia melalui alokasi dan distribusi sumber daya yang terbatas yang berada dalam koridor yang mengacu pada pengajaran Islam tanpa memeberikan kebebasan individu atau tanpa perilaku makro ekonomi yang berkesinambungan dan tanpa ketidakseimbangan lingkungan (Nurhadi: 2018; Mustafa Edwin, 2006: 16). Menurut Sayyîd Nawab Haider Naqvi, ilmu ekonomi Islam, singkatnya merupakan kajian tentang perilaku ekonomi orang Islam representatif dalam masyarakat muslim modern (Syed Nawab, 2009: 28 ).

Berdasarkan uraian di atas, dapat disimpulkan bahwa ekonomi Islam adalah suatu cabang ilmu pengetahuan yang berupaya untuk memandang, menganalisis, dan akhirnya menyelesaikan permasalahan-permasalahan ekonomi dengan cara-cara yang Islami. Menurut Abdul Mannan, ilmu ekonomi Islam tidak hanya mempelajari individu sosial melainkan juga manusia dengan bakat religius manusia itu sendiri (Muhammad Abdul, 1997: 20-22). IImu Ekonomi Syari'ah adalah ilmu yang mempelajari aktivitas atau perilaku manusia secara aktual dan empirikal, baik dalam produksi, distribusi, maupun konsumsi berdasarkan Syari'at Islam yang bersumber al-Qur'an dan ss-Sunnah serta ljma'para ulama dengan tujuan untuk mencapai kebahagiaan dunia dan akhirat (Abdul Mannan, 2009: 29).

Lembaga keuangan syariah (LKS) adalah lembaga yang dalam aktifitasnya, baik penghimpunan dana maupun dalam rangka penyaluran dananya memberikan 

189)

dan mengenakan imbalan atau dasar prinsip syariah yaitu jual beli dan bagi hasil (Muhammad abdul karim, 2010: 3). Lembaga Keuangan Syariah (LKS) menurut Dewan Syariah Nasional (DSN) adalah lembaga keuangan yang mengeluarkan produk keuangan syariah dan yang mendapat izin operasional sebagai lembaga keuangan syariah. Definisi ini menegaskan bahwa suatu LKS harus memenuhi dua unsur, yaitu unsur kesesuaian dengan syariah Islam dan unsur legalitas operasi sebagai lembaga keuangan. Maka keuangan syariah adalah transaksi keuangan yang ada dilakukan secara syariah, sedangakan umumnya dilaksanakan didalam suatu lembaga keuangan, sehingga keduanya disebut lembaga keuangan syariah (Nurhadi: 2018).

Bisnis Islam adalah serangkaian aktivitas bisnis dalam berbagai bentuknya yang tidak dibatasi jumlah (kuantitas) kepemilikan hartanya (barang/jasa) termasuk profitnya, namun dibatasi dalam cara perolehan dan pendayagunaan hartanya (ada aturan halal dan haram) (Yusanto, 2002: 18). Sebetulnya cara bisnis syari'ah tidak jauh berbeda dari bisnis pada umumnya, yaitu upaya mengusahakan barang dan jasa untuk memenuhi kebutuhan konsumen. Tetapi segi aspek syariah inilah yang membedakan dengan bisnis lainnya. Bisnis syariah adalah segala usaha manusia dalam memenuhi kebutuhan hidup berupa aktifitas produksi, distribusi, konsumsi dan perdagangan baik berupa barang maupun jasa yang sesuai dengan aturan-aturan dan hukum-hukum Allah yang terdapat dalam al Qur'an dan Sunnah. Bisnis Syariah adalah usaha atau kegiatan yang dilakukan oleh orang per orang, kelompok orang, badan usaha yang berbadan hukum atau tidak berbadan hukum dalam rangka memenuhi kebutuhan yang bersifat komersial dan tidak komersial menurut prinsip syariah. Bisnis syari'ah adalah ekonomi atau perihal yang mengurus dan mengatur kemakmuran berdasarkan agama atau aturan-aturan yang telah disyariatkan oleh Islam, atau pengaturan kemakmuran berdasarkan prinsip ekonomi dalam Islam (Dahlan, 2010: 97).

Defenisi-defenisi ekonomi Islam, keuangan Islam dan Bisnis Islam yang telah peneliti jelaskan diawal sub bahasan ini, maka dapat peneliti ambil kesimpulan perbedaan dari ketiganya adalah pada objek kegiatan ekonominya. Ekonomi Islam secara kegiatan ekonomi Islam secara Makro, sedangkan keuangan Islam kegiatan ekonomi yang bersifat Mikro, demikian juga denga Bisnis Islam bahagian dari ekonomi Islam, artinya bisnis Islam terletak antara ekonomi Islam dengan keuangan Islam, namun saling berkaitan, tujuan akhir dari ketiganya adalah untuk memenuhi kebutuhan manusia / masyarakat / penduduk, baik orang perorang atau individu, maupun kelompok atau golongan (Nurhadi: 2018).

$$
\text { Kegiatan mu'âmalah }
$$

iqtishâdiyah atau ekonomi meliputi produksi (Dwi Suwiknyo: 233-239), 
Sudirman M. Johan, Nurhdi, Akhmad Mujahidin, Ahmad Rofiq, Mawardi Muhammad Saleh; Konsep Hikmat Al-Tasyrî' sebagai Asas Ekonomi dan Keuangan Bisnis Islam Menurut Ali Ahmad Al-Jurjawi (1866-1961M) dalam Kitab Hikmat Al-Tasyrî' Wa Falsafatuhu

distribusi (Dwi Suwiknyo: 93-96) dan komsumsi (Dwi Suwiknyo: 149-159). Ketiga hal tersebut tertuang dalam hikmah-hikmah dari mu'âmalah yang telah penulis sebutkan sebelum pembahasan ini, serta meliputi 26 jenis lebih kegiatan mu'âmalah yang akan diterangkan akan datang dalam sub bahasan ini. Pada sub bahasan ini penelis akan membagi tipologi ekonomi menurut al-Jurjawi menjadi empat pokok bahasan, yaitu: dimensi jual beli dalam bisnis Islam, dimensi mudlarabah dalam perbankan syariah dan dimensi muzara'ah dalam produk ekonomi Islam serta dimensi murabahah dalam lembaga keuangan Islam. Penjelasnya berkaitan dengan empat tipologi tersebut sesuai dengan bahasan yang ada dalam kitab hikmah al-Tasyri' wa falsafatuhu menurut peneliti yang sudah di elaborasikan dengan pemikiran peneliti dan analisis pembanding pendapat para ulama adalah sebagai berikut:

a. Dimensi Jual Beli dalam Bisnis Islam

1) Hikmah Jual Beli

2) Hikmah Murabahah

3) Hikmah Jual Beli Salam

4) Hikmah Wakalah

5) Hikmah Kafalah

6) Hikmah Khiyar
7) Hikmah Syuf'ah

8) Hikmah Iqalah

9) Hikmah Riba

10) Hikmah Maisir

b. Dimensi Mudharabah dalam Bank Syariah

1) Hikmah Mudharabah

2) Hikmah Syirkah

3) Hikmah Qismah

4) Hikmah Qardh

5) Hikmah Hiwalah

6) Hikmah Rahn

7) Hikmah Ariyah

8) Hikmah ljarah

c. Dimensi Muzara'ah dalam Produk Ekonomi Islam

1) Hikmah Muzara'ah

2) Hikmah Musaqah

3) Hikmah As-Syirbu

4) Hikmah Ihyau alMawat

d. Dimensi Murabahah dan Lembaga Keuangan Islam

Setelah peneliti menjelaskan hikmah-hikmah dalam muamalah ekonomi menurut al-Jurjawi dalam kitab hikmah al-Tasyri', maka dapat disimpulkan klasifikasi, corak, model, tipe ekonomi dan keuangan menurut al-Jurjawi menurut peneliti, lihat tabel sebagai berikut (Nurhadi: 2018): 
Al-Fikra: Jurnal IImiah Keislaman, Vol. 17, No. 1, Januari - Juni, 2018 (147 189)

Tabel III

Hikmat Al-Tasyri' Asas Ekonomi dan Keuangan dalam Bisnis Islam Menurut Ali Ahmad Al-Jurjawi

\begin{tabular}{|c|l|l|l|l|}
\hline No & $\begin{array}{l}\text { Dimensi } \\
\text { Jual Beli dalam } \\
\text { Bisnis Islam }\end{array}$ & $\begin{array}{l}\text { Dimensi } \\
\text { Mudlârabah } \\
\text { dalam } \\
\text { Syariah }\end{array}$ & $\begin{array}{l}\text { Dimensi } \\
\text { Muzâra'ah } \\
\text { dalam Produk } \\
\text { Ekonomi Islam }\end{array}$ & $\begin{array}{l}\text { Dimensi } \\
\text { Murâbahah } \\
\text { dan Lembaga } \\
\text { Keuangan } \\
\text { Islam }\end{array}$ \\
\hline $\mathbf{1}$ & Hikmah Jual Beli & $\begin{array}{l}\text { Hikmah } \\
\text { Mudlarabah }\end{array}$ & $\begin{array}{l}\text { Hikmah } \\
\text { Muzara'ah }\end{array}$ & $\begin{array}{l}\text { Hikmah } \\
\text { Murabahah }\end{array}$ \\
\hline $\mathbf{2}$ & $\begin{array}{l}\text { Hikmah } \\
\text { Murabahah }\end{array}$ & Hikmah Syirkah & $\begin{array}{l}\text { Hikmah } \\
\text { Musaqah }\end{array}$ & $\begin{array}{l}\text { Hikmah Jual } \\
\text { Beli }\end{array}$ \\
\hline $\mathbf{3}$ & $\begin{array}{l}\text { Hikmah } \\
\text { Jual Beli Salam }\end{array}$ & Hikmah Qismah & $\begin{array}{l}\text { Hikmah } \\
\text { As-Syirbu }\end{array}$ & $\begin{array}{l}\text { Hikmah } \\
\text { Jual Beli Salam }\end{array}$ \\
\hline $\mathbf{4}$ & Hikmah Wakalah & Hikmah Qardl & $\begin{array}{l}\text { Hikmah } \\
\text { lhyau al-Mawat }\end{array}$ & $\begin{array}{l}\text { Hikmah } \\
\text { Wakalah }\end{array}$ \\
\hline $\mathbf{5}$ & Hikmah Kafalah & Hikmah Hiwalah & & Hikmah ljârah \\
\hline $\mathbf{6}$ & Hikmah Khiyar & Hikmah Rahn & & \\
\hline $\mathbf{7}$ & Hikmah Syuf'ah & Hikmah Ariyah & & \\
\hline $\mathbf{8}$ & Hikmah lqalah & Hikmah ljârah & & \\
\hline $\mathbf{9}$ & Hikmah Riba & & & nelayan yang \\
\hline $\mathbf{1 0}$ & Hikmah Maisir & & \multicolumn{2}{|l|}{ contohnya adalah } \\
\hline
\end{tabular}

1. Analisis Tipologi Ekonomi dan Keuangan dalam Bisnis Islam Menurut AlJurjawi

Pembahasan dalam sub judul ini masih berkaitan dengan empat dimensi tipologi dalam ekonomi dan keuangan menurut alJurjawi di atas. Kegiatan ekonomi terdiri dari tiga hal yakni produksi (Muhammad Djakfar, 2007: 109), distribusi (Yusuf, 1995: 31) dan konsumsi. Tetapi, kegiatan ekonomi juga dapat terjadi secara langsung dari produksi ke konsumsi, menangkap ikan untuk dikonsumsi sendiri. Dari sekian banyak jenis mu'âmalah iqtishâdiyah menurut AlJurjawi dalam kitabnya Hikmat alTasyri' wa falsafatuhu, sekitar 26 macam, maka yang termasuk tipologi kegiatan ekonomi secara umum yang meliputi produksi (Ahmad al-Haritsi: 37)/penawaran, distribusi (H. Muh. Said, 2008: 81: 91-94; Sofyan, 2011: 140; Akhmad, 2010: 21) dan konsumsi (H. Muh. Said, 2008: 81; Muhammad Djakfar, 2007; Rafiq, 2012: 182)/permintaan.

Tabel: IX

Analisis Tipologi Jenis Kegiatan Ekonomi Menurut al-Jurjawi

\begin{tabular}{|c|l|l|l|}
\hline \multirow{2}{*}{ No } & \multicolumn{3}{|c|}{ Tipologi Jenis Kegiatan Ekonomi } \\
\cline { 2 - 4 } & Produksi & Distribusi & Konsumsi \\
\hline 1 & As-Syirbu & Zakat & Zakat \\
\hline
\end{tabular}


Sudirman M. Johan, Nurhdi, Akhmad Mujahidin, Ahmad Rofiq, Mawardi Muhammad Saleh; Konsep Hikmat Al-Tasyrî' sebagai Asas Ekonomi dan Keuangan Bisnis Islam Menurut Ali Ahmad Al-Jurjawi (1866-1961M) dalam Kitab Hikmat Al-Tasyrî’ Wa Falsafatuhu

\begin{tabular}{|c|c|c|c|}
\hline 2 & IhyaulMawat & Wakaf & Infaq \\
\hline 3 & Muzara'ah & Infaq & Sedekah \\
\hline 4 & Musaqah & Sedekah & Hibah \\
\hline 5 & Syirkah & Hibah & Jual Beli \\
\hline 6 & Syirkah Inan & Jual Beli & Murabahah \\
\hline 7 & Syirkah Shana' & Murabahah & Transaksi Salam \\
\hline 8 & Syirkah Wujuh & Transaksi Salam & Khiyar \\
\hline 9 & Mudharabah & Khiyar & Iqalah \\
\hline & & Iqalah & Syuf'ah \\
\hline & & Syuf'ah & $\begin{array}{l}\text { Riba (ekonomi } \\
\text { konvensional) }\end{array}$ \\
\hline & & $\begin{array}{l}\text { Riba (ekonomi } \\
\text { konvensional) }\end{array}$ & $\begin{array}{l}\text { Maisir (ekonomi } \\
\text { konvensional) }\end{array}$ \\
\hline & & $\begin{array}{l}\text { Maisir (ekonomi } \\
\text { konvensional) }\end{array}$ & \\
\hline \multirow{2}{*}{ No } & \multicolumn{3}{|c|}{ Tipologi Jenis Kegiatan Ekonomi Secara Bersamaan } \\
\hline & Produksi & Distribusi & Konsumsi \\
\hline 1 & Wakalah & Wakalah & Wakalah \\
\hline 2 & Kafalah & Kafalah & Kafalah \\
\hline 3 & Hiwalah & Hiwalah & Hiwalah \\
\hline 4 & Qismah & Qismah & Qismah \\
\hline 5 & Qardh & Qardh & Qardh \\
\hline 6 & Rahn & Rahn & Rahn \\
\hline 7 & Ariyah & Ariyah & Ariyah \\
\hline 8 & ljarah & ljarah & ljarah \\
\hline 9 & IhyaulMawat & & IhyaulMawat \\
\hline 10 & Muzara'ah & & Muzara'ah \\
\hline 11 & Musaqah & & Musaqah \\
\hline
\end{tabular}

\section{KESIMPULAN}

Adapun kesimpulan dalam penelitian ini sebagai jawaban dari rumusan masalah adalah:

1. Konsep hikmat al-Tasyri' menurut Ali Ahmad al-Jurjawi yang di tuangkan dalam kitab hikmt al-Tasyri' wa Falsafatuhu atau defenisi Hikmat al-Tasyri' (maqashid syariah)-nya Al-Jurjawi dalam kitab tersebut adalah:

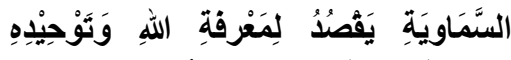

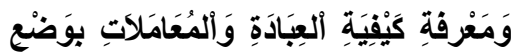
وَالنَّهَي عَن ألمُنْكَوَمَصْلَدَ

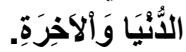

Artinya: Hikmat al-Tsyri adalah hikmahhikmah yang menakjubkan dan mencengankan akal pikiran serta memuaskan hati dari syariat-syariat agama 
Al-Fikra: Jurnal IImiah Keislaman, Vol. 17, No. 1, Januari - Juni, 2018 (147 189)

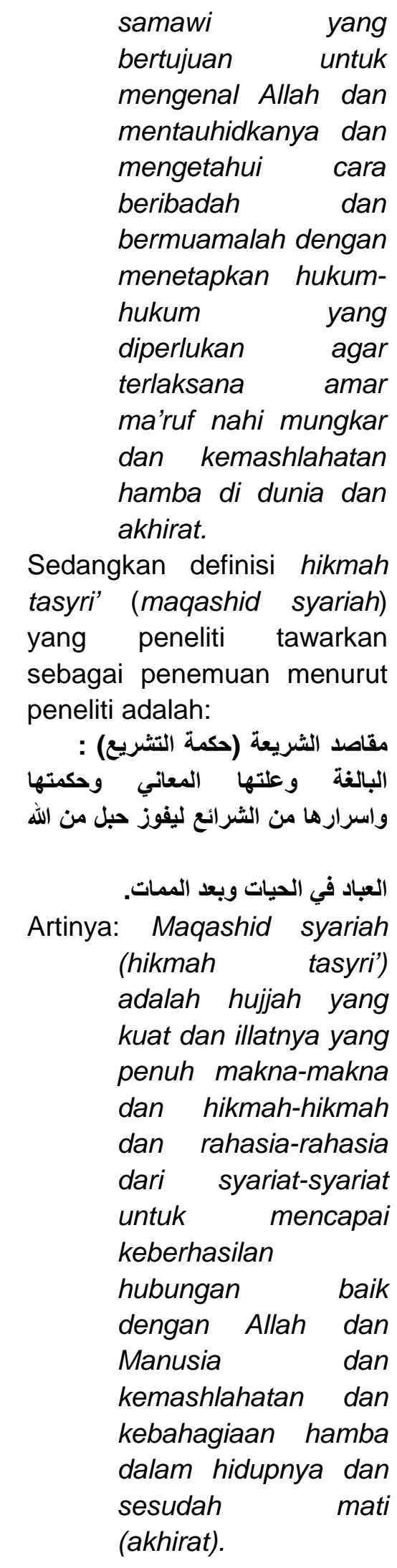

2. Alasan Ali Ahmad al-Jurjawi menjadikan Hikmat al-Tasyri' sebagai asas dalam ekonomi dan keuangan bisnis Islam dalam kitab Hikmat al-Tasyri' wa Falsafatuhu, menurut peneliti mengandung lima hikmah besar, yaitu:

a. Mewujudkan ketundukan pada syariat Allah swt dibuktikan dengan nilai-nilai Ibadah dalam kegiatan Muamalah

lqtishâdiyah sesuai syariah.

b. Melestarikan dan menghidupkan sunah Rasul saw dengan cara mengikuti sunnah Rasul saw dalam bermuamalah lqtishâdiyah sesuai tuntunan-Nya.

c. Menjaga diri dari yang diharamkan Allah dan Rasul-Nya dan mengambil serta menikmati yang dihalalkan-Nya.

d. Menumbuh kembangkan moral (ahklaq mulia dan budi pekerti luhur yaitu sifat amanah, bijaksana, jujur, kesucian

hati/perasaan, dermawan dan sifat zuhud) dan materil (ketenangan dan keuntungan rezki halal berkah serta 
Sudirman M. Johan, Nurhdi, Akhmad Mujahidin, Ahmad Rofiq, Mawardi

Muhammad Saleh; Konsep Hikmat Al-Tasyrî' sebagai Asas Ekonomi dan

Keuangan Bisnis Islam Menurut Ali Ahmad Al-Jurjawi (1866-1961M) dalam Kitab Hikmat Al-Tasyrî' Wa Falsafatuhu




Al-Fikra: Jurnal IImiah Keislaman, Vol. 17, No. 1, Januari - Juni, 2018 (147 189)

produk ekonomi dan keuangan bisnis syariah.

\section{DAFTAR PUSTAKA}

Abbas Arfan, 99 Kaedah Fiqih Muâmalah Kulliyah Tipologi dan Penerapanya dalam Ekonomi Islam dan Perbankan Syariah (Malang: UIN Maliki Press, 2013), cet. II

Abd al-Wahab Khallaf, Ilmu Ushûl alFiqh, (Kairo: Maktabah alDa'wah al-Islâmiyah, 1968

Abd al-Wahhab Khallaf, IImu Ushûl al-Fiqh, (Kairo : Dar alQalam, 1978), cet ke-12.

Abdul Aziz Dahlan dan dkk, Ensiklopedi Hukum Islam, (Jakarta: PT. Ichtiar Baru van hove, 1996)

Abdul Karim Zaidan, al-wajîz fi alUsûl al-Fiqh (Beirut: Muassaiasah ar-Risalah, 2001), cet. VII

Abdul Majid Najjar, Maqâshid alSyari'ah bi ab'âd Jadîdah, (Beirut: Dar al-Gharb alIslamy, 2006)

Abdul Mannan, Hukum Ekonomi Syari'ah Dalam Perspektif Kewenangan Peradilan Agama, (Jakarta : Kencana Prenada Media Group)

Abdul Mujib, Kepribadian Dalam Psikologi Islam, (Jakarta: PT.Raja Grafindo Persada, 2006)

Abdul Wahab Khallaf, IImu usûl alFiqh (Surabaya: alharamaian, 2004), cet. II

Abdullah, Materi Pokok Pendidikan IPS-2: Buku 1, Modul 1,
(Jakarta: Departemen Pendidikan dan Kebudayaan , PPPG Tertulis, 1992)

Abu Hamid al-Gazali, al-Mustasyfa $f i$ 'Ilmu al-Ushûl, (Beirut : Dar al-Kutub al-'Ilmiyah, 1983), Juz I

Abû Ishâq al-Syâtibî, Al-Muwâfaqât, (Bairut: Darul Ma'rifah, 1997), juz 1-2

Achmad Musyahid, Hikmat At-Tasyri dalam Daruriyyah Al-Hamsah (Jurnal Ar-Risalah, Fakultas Syari'ah dan Hukum Universitas Islam Negeri (UIN) Alauddin Makassar, Volume 15 Nomor 2 Nopember 2015)

Adiwarman A. Karim, Ekonomi Makro Islami (Jakarta: PT. Rajawali Pers/RajaGrapindo Persada, 2014)

Aghnam Shofi, Puasa Menurut Syekh Ali Ahmad al-Jurjawi dalam Kitab Himat al-Tasyrî' wa Falsafatuhu (Studi Kajian Aksiologi) (Semarang: Skripsi Fakultas Ushuluddin IAIN Walisongo, 2004)

Agustianto, Urgensi Mashlahah dalam ljtihad Ekonomi Islam, Artikeldi http//:www.agustiantocenter.c om, diakses jum'at 9 Desember 2016 pukul 09.40 wib.

Agustianto, Ushul Fiqh dan Ulama Ekonomi Syariah, Artikel online di http//:www.agustiantocenter.c om, diakses jum'at 9 Desember 2016 pukul 09.35 wib.) 
Sudirman M. Johan, Nurhdi, Akhmad Mujahidin, Ahmad Rofiq, Mawardi

Muhammad Saleh; Konsep Hikmat Al-Tasyrî' sebagai Asas Ekonomi dan

Keuangan Bisnis Islam Menurut Ali Ahmad Al-Jurjawi (1866-1961M) dalam Kitab Hikmat Al-Tasyrî’ Wa Falsafatuhu

Ahmad al-Raisuni, Nazhariyyah alMaqashid 'Inda al-Imam alSyathibi, (Hemdon: alMa'had al-'Alami li al-Fikri alIslami, 1995)

Ahmad Alyu Husein Tha'i, alMawazinatu baina alMashalih dirasatu $\mathrm{fi}$ syaisayah syariyyah (Darunafais, tp, $2008 \mathrm{M}$ )

Ahmad ar-Raisuni, Nazhâriyyat alMaqâshid ,inda al-Imâm ashShâtibi, (Beirut: al-Maahad al-Alami li al-Fikr al-Islâmi, 1992)

Ahmad Azhar Basyir, Pokok-Pokok Persoalan Filsafat Hukum Islam( Yogyakarta: UII Pres, 1984)

Ahmad el-Najjar, Bank Fawâ'îd ka Istirâtijîyah lil Tanmiyah allqtishâdîyah (Jeddah: King Abdul Aziz University Press, 1972)

Akhmad al-Raisuni, Nazhâriyât alMaqâshid "inda al-Syâtibi, (Rabath ; Dar al-Aman, 1991) Akhmad Mujahidin, Ekonomi Islam Sejarah, Konsep, Instrumen, Negara dan Pasar (Jakarta: PT. Raja Grapindo Persada Rajawali Pers, 2013), cet. II

Akhmad Mujahidin, M.Ag, Ekonomi Islam 2, (Pekanbaru, Mujtahadah Press: 2010)

Al-Amidi, Ghâyat al-Maram fi ' IIm alKalâm, Hasan Mahmud 'Abd al-Latif (ed.). (Kaherah: alMajlis al-A la lial-Shu'un alIslamiyyah, $1971 \mathrm{M} / 1391 \mathrm{H}$ )

Al-Ghazali al-Musytasyfa, juz III (Mesir : al-Mathba'ah alilmiyyah, $1324 \mathrm{H}$ )
Ali Ahmad al-Jurjawi, Hikmat alTasyrî' wa Falsafatuhu, (Bairut Lebanon : Daar alFikr, 1994 M/ 1414 H)

Ali Ahmad al-Jurjawi, Hikmat alTasyri' wa Falsafatuhu,diterjemahkan oleh Faisal Sakeh, dkk., Indahnya Syariát Islam, (Jakarta, Gema Insani, 2006 )

Ali Ahmad al-Jurjâwîy terjemahan oleh Faisal Shaleh, Indahnya Syariat Islam (Jakarta: Gema Insani Press, 2006), cet. I

Ali Ahmad al-Jurjâwîy, Hikmat alTasyrî' wa Falsafatuhu, (Bairut Lebanon : Daar alFikr, 1994 M/ 1414 H)

Ali Ahmad al-Jurjâwîy, Mulakhas Kitâbinâ Hikmat al-Tasyrî' wa Falsafatuhu (Cairo Mesir: Maktabah al-Tijâriyah Jamî'at al-Azhar Ilmiyah, $1354 \mathrm{H}$ / $1937 \mathrm{M}$ )

Ali Ibrahim Hasyim, Ekonomi Makro (Jakarta: PrenadaMedia Group, 2016)

Al-Izz bin Abdul Salam, Qawâid alAhkâm fi Masalih al-Anâm, (Beirut, Dar al-Ma'rifah, t.th), Jilid 1

Allal Al-Fasy, Maqâshid asy-Syarîa'ah al-Islâmiyyah wa Makârimuha, (KSA: Dârul Garb Al-Islamy. 1993), (Cet.5)

Al-Muzakkir, Hikmah Muâmalah Perspektif Ali Ahmad alJurjâwîy Dalam Kitab Hikmat al-Tasyrî' Wa Falsafatuhu, tesis tidak diterbitkan (Program Pascasarjana Kosentrasi Al-Ahwal Al- 
Al-Fikra: Jurnal IImiah Keislaman, Vol. 17, No. 1, Januari - Juni, 2018 (147189)

Syakhshiyyah UIN Suska

Riau, 2017)

Al-Sarakhsi, Ushûl al-Sarakhs, Juz II, (Kairo : Dar al-Kitab al'Arabi, $1372 \mathrm{H}$ )

Al-Syathibi, al-Muwafaqât, Juz IV, (Beirut : Dar al-Fikr, tt)

Amir Syarifuddin, Ushûl fiqih, (Jakarta : Kencana, 2009), jilid 2, cet. V

Amir Syarifudin, Ushûl Fiqh, (Jakarta : Kencana Media Grup, 2009), cet. Ke-4

Andriyaldi, Teori Maqashid Syariah Dalam Perspektif Imam Muhammad Thahir Ibnu 'Asyur (Jurnal Islam dan Realitas Sosial, Vol. 7, No. 1, Januari-Juni 2014)

Anif Punto Utomo, Dua Dekade Ekonomi Syariah, Menuju Kiblat Ekonomi Islam (Jakarta: Gres, Publishing, 2014)

Ar-Raisuni, Muhâdaharât fi Maqâshid as-Syariat.diakses dari

www.raissouni.org/def.asp?c odelangue $=6 \& p o=$ pada tanggal 7 Februari 2017 jam 13.10 Wib.

Asafri Jaya Bakri, Maqâshid alSyarîah Menurut AlSyathibîy, (Jakarta: PT Raja Grafindo Persada, 1996)

Ascarya, Akad dan Produk Bank Syariah (Jakarta: PT. Rajagrafindo, 2015)

Asri Yaqien, Lembaga Keunagn Non Bank Syariah, artikel online http://asriyaqien.blogspot.co.i d/2014/10/lembagakeuangan-non-banksyariah.html.diakses tanggal
22 Februari 2017 Jam 20.00 Wib

Beekun, Rafiq Issa, Islamic Business Ethict, Virginia: Internationallnstitute Islamic Thought, 1997.

Buku Panduan Penulisan Tesis Disertasi yang diterbitkan Program Pasca Sarjana Universitas Islam Negeri Sultan Syarif Kasim Riau, Buku Panduan Penulisan Tesis dan Disertasi (Pekanbaru, PPs UIN Suska Riau, 2016-2017)

Dahlan Abdul Aziz dan dkk, Ensiklopedi Hukum Islam, (Jakarta: PT. Ichtiar Baru van)

Daud Vicary Abdullah dan Keon Chee, Islamic Finance Why it Makes Sense (Pent: Satrio Wahono, (Jakarta: Zaman, 2012) cet 1

Depag RI, Ensiklopedia Hukum Islam,(Jakarta: Depag $\mathrm{RI}, 1997)$

Didiek Ahmad Supadie, Sistem Lembaga Keuangan Ekonomi Syariah dalam Pemberdayaan Ekonomi Rakyat (Semarang: PT. Pustaka Rizki Putra, 2013), cet. I

Edang Hidayat, Transaksi Ekonomi Syariah (Bandung: PT. RemajaPosdakarya, 2016)

Fathurrahman Djamil, Filsafat Hukum Islam, (Jakarta : Logos, 1997)

Galuh Nashrullah Kartika Mayangsari $\mathrm{R}$ dan $\mathrm{H}$. Hasni Noor, Konsep Maqashid AlSyariah Dalam Menentukan 
Sudirman M. Johan, Nurhdi, Akhmad Mujahidin, Ahmad Rofiq, Mawardi Muhammad Saleh; Konsep Hikmat Al-Tasyrî' sebagai Asas Ekonomi dan Keuangan Bisnis Islam Menurut Ali Ahmad Al-Jurjawi (1866-1961M) dalam Kitab Hikmat Al-Tasyrî’ Wa Falsafatuhu

Hukum Islam (Perspektif AlSyatibi dan Jasser Auda) (Jurnal Dosen Program Studi Hukum Ekonomi Syariah I Fakultas Studi Islam Universitas Islam Kalimantan MAB Banjarmasin-Indonesia I

ganash_kamasaro@yahoo.c o.id I HP: 085254849294, lqtisadiyah Jurnal Ekonomi Syariah dan Hukum Ekonomi Syariah, ISSN Elektronik: 2442-2282, Volume I, Issue I, Desember 2014)

Ghofar Shidiq, Teori Maqashid AlSyari'ah dalam Hukum Islam (Jurnal Dosen Fakultas Agama Islam Universitas Islam Sultan Agung Sultan Agung Vol XLIV No. 118118 Juni-Agustus 2009)

H. Mohammad Daud, Hukum Islam (Jakarta : PT. Raja Grafindo Persada)

H. Muh. Said, Pengantar Ekonomi Islam (Pekanbaru: Suska Press, 2008)

Hand Out kitab Mulakhâs Kitâbinâ Hikmat al-tasyri' wa Falsafatuhu dapat diakses dalamwibesite.online.dengan .alamat:http://kadl.sa/item.as px?id=PW8UHBYDsm9d1aW YxnthLgoLED27no1D7WixN DiHHwo2wjtx1wtPUNZtOJnQ CgD,dan.http://kadl.sa/pdfvie wer.aspx?filename=pw8uhby dsm9d1awyxnthlgoled27no1 d7wixndihhwo2wjtx1 wtpunzto jnqcgd.diakses.21Desember 2017.Jam16.00.Wib.
Hans Wehr, A Dictionary of Modern Written Arabic (London: McDonald \& Evan Ltd., 1980)

Hardijan Rusli, Metode Penelitian Hukum Normative : Bagaimana?" law review fakultas hokum universitas pelita harapan (t.th: t.p, 2006). Volume V No. 2

Heri Sudarsono, "Bank dan Lembaga Keuangan Syariah", (Yogyakarta: Ekonesia, 2008)

Heri Sudarsono, Bank dan Lembaga Keuangan Syariah, (Yogyakarta: Ekonisa, 2003)

Heri Sudarsono, Bank dan Lembaga Keuangan Syariah, (Yogyakarta: Ekonisia, 2007), jilid II.

Huderi Beik, Ushûl Fiqh, (Beirut ; Daar al-Fikr, 1988).

Ibn Manzur al-Afriqi, Lisân al-'Arab (Beirut: Dar ash-Shadr, t.th), juz VIII

Ibnu al-Qayyim al-Jauziyah, l'lâm alMuwaqqiîn, Juz I, (Beirut : Dar al-Jil, tt)

Ibnû Qayyîm al-Jawzîyyah, l'lam alMuwaqqiîn, (Beirut, Dar alKutub al-IImiyyah, 1996), Juz III

Ibrahim Basyuni Madku'r, Durû's Fi al-Tarîkh Wa al-Falsafah, (Kairoh : al-Amirah, 1942)

Idris Ismail, Penyerapan Fatwa Dewan Syariah Nasional (DSN-MUI) dalam Sistem Peraturan Perundangan (Kajian Fiqih Siasyah), Disertasi tidak diterbitkan (Program Pascasarjana Kosentrasi Al-Ahwal Al- 
Al-Fikra: Jurnal IImiah Keislaman, Vol. 17, No. 1, Januari - Juni, 2018 (147 189)

Syakhshiyyah UIN Suska
Riau, 2017)

Ilal bin Abdul Wahid bin Abdu Salam al-Fasiy al-fahriy, Maqashid Syariah wa Makarimuha (Beirut: Darul al-Gharbi alIslami, 1999 M), jilid V

Imam al-Syafi'l, al-Risâlah, (Bairut : al-Maktabah al-'ilmiyah, tt)

Imam ibnu Asyur, Maqashid alSyariah al-Islamiyyah (Jordan: Dar Nafais,2001) cet.II

Imam Taqiyuddin Abu Bakar alHusaini, Khifayatul Akhyar, (Bina IImu.Surabaya, 1997)

Inggi H Ashien, Investasi Syariah di Pasar Modal, (Jakarta: Gramedia Pustaka Utama,2000)

Irfandi, Maqashid Al-Syari'ah Menurut Muhammad Thahir Ibn 'Asyur (Makalah Mata Kuliah Maqashid Syariah Program Pascasarjana Jurusan Hukum Keluarga Sekolah Tinggi Agama Islam Negeri (STAIN) Pekalongan 2014)

Ismail Muhammad Syah dkk, tulisan Amir Syarifuddin (Pengertian dan Sumber hukum Islam), Filsafat Hukum Islam, (Jakarta : Bumi Aksara, 1991)

Izuddin bin Abdi Salam, Qawaidul Ahkam, (Dimisko: Darul Kolam, 2000 M)

Jabbar Sabil, Menalar Hukum Tuhan, (Banda Aceh ; LKAS, 2009)

Jasser Auda, Maqasid al-Shari'ah as Philosophy of Islamic Law a
System Approach, (Herndon: IIIT, 2008)

Juhaya S. Praja, Filsafat Hukum Islam, (Bandung ; Yayasan Piara, 1989)

Juhaya S. Praja, Tafsir Hikmah seputar ibadah, muamalah, jin dan manusia, (Jakarta: Kencana, 2008)

Julius R. Latumaerissa, Bank dan Lembaga Keuangan Lainya (Jakarta: Salemba Empat, 2012)

Kasmir, Bank dan Lembaga Keuangan Lainya (Jakarta: PT. Raja Granpindo Persada, 2002)

Khalifah Babkrin Husain, Falsafah Maqashid Syariah (Qahirah: Maktabah Wahabiyah, 1421 H / 2000 M)

Komaruddin Satradipoera, Sejarah Pemikiran Ekonomi: Suatu Pengantar Teori dan Kebijaksanaan Ekonomi, (Bandung: Kappa-Sigma, 2001)

La Jamaa, Dimensi llahi dan Dimensi Insani dalam Maqashid al-Syari'ah (Jurnal IAIN Ambon Jl. Kebun Cengkeh Batu Merah Atas Ambon Maluku Tlp. 085243201370, Asy-Syir'ah Jurnal IImu Syari'ah dan Hukum Vol. 45 No. II, JuliDesember 2011)

M. Hasbi Ash-shiddieqy, Falsafah Hukum Islam (Jakarta: Bulan Bintang, 976)

M. Nur Rianto al-Arif, Teori Makro Ekonomi Islam (Bandung: CV. Alfabeta, 2010) 
Sudirman M. Johan, Nurhdi, Akhmad Mujahidin, Ahmad Rofiq, Mawardi

Muhammad Saleh; Konsep Hikmat Al-Tasyrî' sebagai Asas Ekonomi dan

Keuangan Bisnis Islam Menurut Ali Ahmad Al-Jurjawi (1866-1961M) dalam Kitab Hikmat Al-Tasyrî’ Wa Falsafatuhu

M. Quraish Shihab, Tafsîr al-Misbah, (Jakarta :Lentera hati, 2007), cet. VIII, volume ke 8

Muh. Said, Pengantar Ekonomi Islam (Pekanbaru: Suska Press, 2008)

Muhammad Abû Zahrah, Ushûl Fiqih, terj Syaiful Ma'shum (Jakarta: Pustaka Firdaus, 2011)

Muhammad Abduh Muhyi, Uang dan Lembaga Keuangan,

PDF.Power Poin 3/28/2011

Muhammad abdul karim, Kamus Bank Syariah (Yogjakarta : asnaliter)

Muhammad Abdul Manan, Islamic Economics, Theory and Practice, (India: Idarah Adabiyah, 1980)

Muhammad Abdul Mannan, Teori Dan Praktik Ekonomi Islam, (Yogyakarta : PT. Dana Bhakti Wakaf, 1997)

Muhammad Abu Zahra, Ushûl alFiqh (Beirut : Dar al-Fikr alArabi, 1985)

Muhammad Abu Zahrah, Ushûl alFiqhi, (t.tp : dar al-fikr al'arabi, t.th)

Muhammad bin Farhun, at-Tabsîrah al-Hukkâm, (Dar al-Maktabah al-Ilmiyyah, Mesir, 1301H)

Muhammad dan Lukman Fauroni. 2002. Visi al-Qur'an tentang Etika danBisnis, Jakarta: Salemba Diniyah

Muhammad Djakfar, Agama, Etika, dan Ekonomi Wacana Menuju Pengembangan Ekonomi Rabbaniyah. Penerbit: UIN-Malang Press, September 2007.
Muhammad Djakfar, Agama, Etika, dan Ekonomi, (UIN Malang Press, Malang, cet.I, 2007)

Muhammad Kamil Musa, al-Madkhal ila al-Tasyrî' al-Islâmi, (Beirut : Mu'assasah al-Risalah, 1989)

Muhammad Mufid, Usul Fiqih Ekonomi dan Keuangan Kontemporer, Dari Teori ke Aplikasi (Jakarta: Preanada Media Group, 2016)

Muhammad Sa'adi bin Ahmad bin Ma'ud al-Yubi, Maqâshid asy-Syarî'ah al-Islâmiyah wa Alaqâtuha bi al-Adillah asySyar'îyyah (KSA: Dâr alHijrah li an-Nasyr wa atTauzi', 1998), Cet.1

Muhammad Syafi'i Antonio, Bank Syariah dari Teori ke Praktek (Jakarta: Gema Insani Press, 2014), cet. XXII

Muhammad Syarifudin, Lembaga Perekonomian Umat (Jurnal online, t.th)

Muhammad Thahir bin 'Asyur, Maqâshid al-Syarî'ah alIslâmîyyah, (Amman: Dar alNafa'is, 2001)

Muhammad Thahir bin Muhammad Asyut al-Tunisiy, Maqashid Syariah al-Islamiy (Lebanon: Darul Kutub IImiyah, 1996 M)

Muslehuddin, Philosopy of Islamic Law and the Orientalis, (Lahore : Islamic Publication, 1980), cet. II

Mustafa Edwin Nasution dkk, Pengenalan Eksklusif Ekonomi Islam, (Jakarta: Kencana, 2006) 
Al-Fikra: Jurnal IImiah Keislaman, Vol. 17, No. 1, Januari - Juni, 2018 (147 189)

Musthafa Syalabi, Ta'lîl al-ahkâm, (Kairo : Dar al-Nahdhah, 1981)

Nana Herdiana Abdurrahman, Manajemen Bisnis Syariah dan Kewirausahan, (Bandung: Cv. Pustaka Setia, 2003), Cet. I

Naqvi, Syed Nawab Haider, Etika dan IImu Ekonomi Suatu Sintesis Islami, terj.Husin Anis, (Bandung: Mizan, 1993)

Nasrun Haroen, Ushûl Fiqh, (Jakarta : Logos, 1996), cet.ke-1

Nurhadi, Konsep Hikmat Al-Tasyrî' Sebagai Asas Ekonom Dan Keuangan Bisnis Islam Dalam Kitab Hikmat Al-Tasyrî' Wa Falsafatuhu Karya Ali Ahmad Al-Jurjawi (18661961M) (Disertasi Doktor Pascasarjana UIN Suska Riau, 2018).

Nurizal Ismail, Maqâshid Syarî’ah dalam Ekonomi (Yogyakarta: Smart WR, 2014)

Nurmawan, Uang dan Lembaga Keuangan, PDF. Modul Pembelajaran Mata Kuliah Ekonomi Eko.2.03

Nuruddin Mukhtar al-Khadimi, alljtihâd al-Maqâsidi (Qatar: t.p, 1998)

Nurul Huda dan Mohammad Haykal, Lembaga Keuangan Islam: Tinjauan teoritis dan Praktis, (Jakarta: Kencana Prenada Media Group, 2010)

Nurul Huda dan Mustafa Edwin Nasution, Investasi pada Pasar Modal Syariah, (Jakarta: Kencana, 2007)
OJK Wibesite, IKNBSyariah, ojk online http://www.ojk.go.id/id/kanal/i knb/Pages/IKNB-

Syariah.aspx.diaskes tanggal 22 Februari 2017 Jam 20.45 Wib.

Otoritas Jasa Keuangan, Bloket Perbankan Indonesia tahun 2014, Edisi Pertama.

Pusat Pengkajian dan Pengembangan Ekonomi Islam (P3El), Ekonomi Islam, (Jakarta: PT Raja Grafindo Persada, 2011)

Rafiq Yunus al-Mishri, Ushul allqtishad al-Islami, (Dar alQalam, Damaskus, 2012), cet. V

Richard Lipsey G dan Peter Steiner O, Economics, (New York: Harper \& Row, Publisher, 1981)

Sa'di AbiJib, Qamûs al-Fiqih allughah wa al-Istilâhi, (Suria : Daar al-Fikr, 1998)

Sabariyah, Kerangka Berpikir Ali Ahmad al-Jurjâwîy dalam Menetapkan Hikmat alTasyrî' Pada Kitab Hikmat alTasyrî' Wa Falsafatuhu, tesis tidak diterbitkan (Program Pscasarjana Kosentrasi AlAhwal Al-Syakhshiyyah UIN Suska Riau, 2011)

Saifuddin al-Amidi, al-Ihkâm fi alûshûl al-Ahkâm, (Beirut : Daar al-Fikr, tt)

Satria Effendi M. Zein, Ushûl Fiqh (Cet. I; Jakarta: Kencana, 2005)

Sigit Triandanu, Bank dan Lembaga Keuangan Lain, (Jakarta 
Sudirman M. Johan, Nurhdi, Akhmad Mujahidin, Ahmad Rofiq, Mawardi

Muhammad Saleh; Konsep Hikmat Al-Tasyrî' sebagai Asas Ekonomi dan

Keuangan Bisnis Islam Menurut Ali Ahmad Al-Jurjawi (1866-1961M) dalam Kitab Hikmat Al-Tasyrî’ Wa Falsafatuhu

:Salemba Empat, 2006), Edisi II

Sofyan S. Harahap, Etika Bisnis dalam Perspektif Islam (Jakarta: Salemba Empat: 2011)

Suhrawardi K. Lubis, Hukum Ekonomi Islam, (Jakarta: Sinar Grafika Cet. III, 2004)

Supriyadi, Pengantar Filsafat Islam,(Bandung: CV Pustaka Setia, 2010), cet. II

Suryan A. Jamrah, Studi IImu Kalam, (Pekanbaru : PPS UIN Suska Riau dan LSFK2P, 2008)

Syafruddin Prawiranegara, Ekonomi dan Keuangan (makna ekonomi Islam) (Jakarta: PT. Dunia Pustaka jaya, 2011)

Syah Walî Allah ad-Dihlawî, Hujjatullah al-Bâlighah, (Beirut: Dar al-Jail, 2005), jiid I, cet. I

Syamsuddin Arif, Mengenal Istilah Filsafat,

http://www.inpasonline.com/.

dikutip dari Muhammad Nuh, Filsafat Dan Hikmah AlTasyri', dalam https://bunga9hati.blogspot.c o.id/2012/05/filsafat-hukumislam.html.diakses.tanggal7J anuari2018.Jam22.00.Wib.

Syed Nawab Haider Naqvi, Menggagas IImu Ekonomi Islam, terj. M. Saiful Anam dan Muhammad Ufuqul Mubin, (Yogyakarta: Pustaka Pelajar, 2009)

Syekh Muhammad Abid as-Sindi, Musnad Syafi'i, (Bandung: Sinar Baru Algensindo, 2000), juz I dan II
Tajul Arifin, Filsafat Hukum Islam (Bandung; Pustaka Setia. 2008)

Thahir bin Asyur, Maqashid AlSyari'ah AlIslamiah, (Amman: Dar alNafais, 2001)

Umar sulaiman al-'asyqar, Tarîkh alFiqh al-Islâmi, (Amman ; Dar al-Nafa'is, 1991)

Veithzal Rivai, dkk, Bank and Financial Institution management Conventional and Sharia Sistem (Jakarta: PT. Rajagarafindo Persada, 2007)

Wahbah al-Zuhaili, Ushûl al-Fiqh alIslâmi (Beirut: Dar al-Fikr, 1986)

Wahbah al-Zuhaili, Ushul al-Fiqh alIslami, (Damsik/Mesir: Dar alFikr, 1996), jiid II

Wiliam Montgomery, Butir-Butir Hikmah Sejarah Islam (Jakarta: Srigunting, 1999)

Yahya Sai'di, Tauzhif Maqashid Syariah fi Fahmi al-Qur'an wa Tafsirihi (t.t: t.p, t.th)

Yanwari Yadi. Djazuli, Lembaga Perekonomian Umat (Jakarta: PT. Raja Grafindo Persada, 2012)

Yazid Afandi, "Fiqh Muâmalah dan Implementasinya dalam Lembaga Keuangan Syari'ah", (Yogyakarta: Logung Pustaka, 2009)

Yusanto, Muhammad Ismail dan Muhammad Karebet Widjajakusuma. Menggagas Bisnis Islami, (Jakarta: Gema Insani Press, 2002)

Yusuf al-Qardawi, Fiqh Maqâshid Syarî́áh, penerjemah $\mathrm{H}$. Arif 
Al-Fikra: Jurnal IImiah Keislaman, Vol. 17, No. 1, Januari - Juni, 2018 (147189)

MunandarRiswanto, (Jakarta

: Pustaka al-Kausar, 2007)

Yusuf al-Qardhawi, Daur al-Qiyam wa al-Akhlak fi al-lqtishadi alIslam, (Maktabah Wahbah, Kairo, 1995)

Yusuf al-Qardlawi, Fiqh Maqashid Syari'ah, terj. H. Arif Munandar
(Jakarta: Pustaka al-Kautsar, 2006)

Yusuf al-Qardlawi, Fiqih Maqashid (Mesir: Daru Syuruq, 2007 M)

Zakiyuddin Sya'ban, Ushûl al-Fiqhi al-Islâmiy, (Kairo : Dar alTa'lif, 1964 H) 